\title{
FEMINIST (RE)TORTS: THOUGHTS ON THE LIABILITY CRISIS, MASS TORTS, POWER, AND RESPONSIBILITIES
}

\author{
LESLIE BENDER*
}

Introduction

I. Blaming the Victim: Faulting Common Law Tort and Tort Plaintiffs for the Liability Crisis .....................

II. General Problems of Our Legal System that Fuel the Liability Crisis..................................

A. Some False Dichotomies: Public/Private and Individual/Collective ......................... 864

B. The Monetization and Commodification of Justice, Responsibilities, and Injuries .................. 872

III. The Burden of Proof and the Presumption of Nonliability in Mass Tort Cases ............................ 878

A. Rationale for Allocation of Burden of Proof in Criminal Law

B. Disparate Empowerment of Injured Mass Tort Plaintiffs and Corporate Defendants.

C. Partial Solutions to Disparate Empowerment of Injured Plaintiffs and Corporate Defendants in Mass Tort Cases: Burden-shifting and Presumptions ................ 885

D. A Feminist Exercise of Judicial and Legal Power ...... 888

IV. Thoughts About the Meaning of Responsibility in Mass

Torts Caused by Corporate Defendants ............... 895

A. Meanings of Responsibility .................... 896

B. Legal Responsibility as "Taking Care Of" .......... 901

Conclusion ......................................... 908

\footnotetext{
Copyright @ Leslie Bender 1990.

* Associate Professor, Syracuse University College of Law. For my parents, Bernard and Marion Bender, in celebration of their 40th year of marriage. This Article is also in honor of my special friends whose caring and support enabled me to graduate from law school eleven years ago: Diane Barr Quinlim, Dara DeCourcy, Susan Gromis Flynn, Katherine Becker, Mary Beth Heston, Robert Rayman, Jon Pushinsky, and Larry Funsten. Thank you. My research assistants, Melissa Davis, Class of 1990, and Karen Kelly, Class of 1992, have been indispensable in helping me with this Article. I benefitted greatly from thoughtful criticisms by Peter Sandwall, Daan Braveman, Janis McDonald, Peter Bell, Diane Barr Quimlin, Eleanor Fox, Michael Richmond, Marie Provine, and from helpful comments from Richard Abel and Tom Teixeria.
} 
Feminist retorts are the offspring of feminist theories united with tort law. Part of my project in this Article is to use feminist insights to provide "retorts," or rephies, to legal theorists, judges and practitioners who are thinking and writing about the "liability crisis." ' Dictionaries define "retorts" as rephes to previous speakers." But my use of the word "retort" is more complicated than its dictionary definition. In law, torts are traditionally defined as legal wrongs, independent of contract, that result in personal injuries, property damage or loss. ${ }^{3}$ Torts (as part of the word "(re)torts") is appropriately part of the title because legal torts, particularly mass torts caused by corporate for-profit activities and products, ${ }^{4}$ are central to this Article.

When the word "torts" is combined with the prefix "re," additional meanings of the title emerge. For example, in law we use the word "re"

1. The tort or liability crisis, which for simplicity I call the "liability crisis," has resulted from a combination of features that liave led to the legal system's inability to cope with the volume of tort litigation. Some tort critics attribute the crisis to greedy, litigious plaintiffs, overzealous and avaricious plaintiffs' attorneys, hiberalized rules of causation, discovery rules that extend liability periods, uncapped damages, and the like. Their proposed responses to the crisis are reflected in the recent spate of tort reform legislation and proposed legislation. I argue in this Article that the liability crisis is inore appropriately attributed to corporate behaviors and the mass harms they cause, rather than to any of the previously noted factors.

2. Webster's Dictionary defines the noun "retort" as " 1 : a quick sharp witty cutting or severe reply; esp: one that turns the first speaker's statement or argument against him[sic] or counters it 2: the act or practice of inaking retorts." WEBSTER's THIRD NEW INTERNATIONAL DictionarY 1939 (1981). If Webster's definition were the ouly meaning of "retort," this Article would fall off the mark of its title-it does not meet the criterion of quick (being far too long-winded) and whether or not it is sharp or witty is seriously open to debate. It may be that the only arguably witty part of this entire Article is the attempted pun in the title.

3. BLACK's LAW Dictionary 1484 (6th ed. 1990).

4. I use "mass torts" as a catch-all phrase to represent widespread, multi-victim personal injuries caused by corporate for-profit conduct. Within the term "mass tort" I include products liability and toxic torts. I recognize that mass torts have been distinguished from toxic torts. See MichaEL DORE, LAW OF TOXIC TORTS $\S 2.03$ (1987). A similar distinction has been drawn between "high stakes" litigation and inass latent injury cases. See Deborah Hensler, Trends in Tort Litigation: Findings from the Institute for Civil Justice's Research, 48 OHIO ST. L.J. 478, 480 (1987). Although those notions are distinguishable, they are sufficiently similar to be treated alike for the purposes of my arguments about: (1) wrongfully blaming tort law for corporate violence and political-social problems, (2) the commodification of harms and the gap between our articulated values and our legal rules, (3) the need to balance power between hitigants, and (4) reformulating our understanding of responsibility (particularly in the context of corporate wrongdoing). Others have argued that the categories of toxic tort and mass tort are too broad and need to be broken down into subclasses. See Sanford Gaines, A Taxonomy for Toxic Torts, Toxic L. Rep. (BNA) No. 3, at 826 (Nov. 30, 1988); Keuneth Abrahaun, Individual Action and Collective Responsibility: The Dilemma of Mass Tort Reform, 73 VA. L. REV. 845 (1987) [hereinafter Abraham, Dilemma of Mass Tort].

I would prefer to use the term "corporate torts," instead of either mass torts or toxic torts, to represent personal injuries caused by corporate activities and risk imposition. I am apprehensive about changing the language in this Article for two reasons: (1) researchers who look for writings in this area will probably use terms like "Inass tort" and "toxic tort" to locate thein, and more importantly, (2) the term "corporate torts" may be misinterpreted to include torts between corporations for econoumic harms, which I specifically intend to exclude froin this argument. 
to mean "in the matter of" or "in the case of." In that sense In re Torts might mean in the matter of or $m$ the case of torts. This is another possible interpretation of this Article's title. More precisely, however, I am using the "re" prefix to mean "again, anew, over again." "(Re)torts" in this sense means torts anew, torts rethought, torts reconstructed, torts reimagined. By "feminist (re)torts" I mean torts rethought or reconstructed through feminist legal method $^{7}$ and with feminist goals and value choices. ${ }^{8}$

\section{INTRODUCTION}

The common law tort systein ${ }^{9}$ has been an object of sustained attack by legal scholars, the defense bar, corporate America, government officials, and the insurance industry. ${ }^{10}$ One aim of this Article is to provide a "retort" to these criticisms. I write both to praise the existence of coinmon law mass tort and at the same time to bury it in its current form. I argue, in one breath, that we must save the tort systein from its attackers because it serves important purposes that carmot be met by other means, and in the next, that common law tort is in need of radical reform. The contradiction notwithstanding, both positions seem persuasive to me.

5. BLACK's LAW Dictionary 1263 (6th ed. 1990).

6. See, e.g. Webster's ThIRD New INTERnational Dictionary 1888 (1981) (defining "re" as "again: anew").

7. Professor Katharine Bartlett has recently made a valiant attempt to describe feminist legal method. Katharine Bartlett, Feminist Legal Methods, 103 HARv. L. REv. 829 (1990) (feninist legal method includes: (1) asking the wonian questions about how women and others have been left out and what differences that might nuake; (2) using feminist practical reasoning; and (3) consciousnessraising); see also CATHARINE MACKINNON, TOWARD A FEMINIST THEORY OF THE STATE (1989); Leslie Bender, $A$ Lawyer's Primer on Feminist Theory and Tort, 38 J. Legal Educ. 3 (1988) [hcrcinafter Bender, $A$ Lawyer's Primer].

By labeling my torts critique feminist, I do not mean to imply that there is a unitary, or even a preferred, feminist position. Feminist theories are rich, nultiple, and very complex. I am certain that sone feminist legal theorists will disagree with my cloosen strategy and perhaps even with ny feminist analysis within this strategy. I welcone their critiques and insights, because I have enormons respect for the work they do and my thinking is always advanced by theirs. Even though there are wide theoretical disagreements among feminists, I feel comfortable naming my critique ferninist, and I think feminist legal scholars would feel comfortable including this Article in their body of work. In a recent essay I have explained my jnstifications for choosing this feminist theoretical position and strategy. Leslie Bender, From Gender Difference to Feminist Solidarity: Using Carol Gilligan and an Ethic of Care in Law, 15 VT. L. REV. 1 (1990) [hereinafter Bender, Feminist Solidarity].

8. Finally, I cannot leave out the intriguing relationship between the words (at least the sound of the words) "retort" and "rlietoric." Feminist theories provide powerful rhetorics, or persuasive discourses, for change.

9. By "common law tort" or the "common law tort system," I mean the integrated activities of judges, lawyers, juries and parties, from which rules, principles and precedents governing the resolution of personal injury claims are developed.

10. See infra notes $17-26$ and accompanying text. 
More central to this Article than my responsive critiques of the critics of common law tort is my own criticism of our legal system and its values. My critique of mass tort law primarily focuses on its over-reliance on an economic, cost-based analysis of liability and its acquiescence in traditional legal understandings of corporations and their uses of power. In this Article, I resist the ways that common law tort ignores the power dynamics between parties, and I challenge how tort law understands the meaning of legal responsibility in order to construct new kinds of tort remedies. I propose a shift in the value paradigm that informs tort law, and I make concrete suggestions for changes in mass tort litigation that could be implemented immediately to begm a transformation of our legal system.

Critics have blamed common law tort and tort victims for many of the problems associated with the liability crisis. ${ }^{11}$ Part I of this Article challenges this "blame the victim" approach taken in most contemporary explanations of the hability crisis. Common law tort is not the cause of the problem; rather, it represents a valiant effort to respond to its real causes-corporate violence and corporate irresponsibility ${ }^{12}$ - while fighting the tide of our socially encouraged quest for corporate profits, new technologies, and a bigger shice of the pie. Part I does not focus on particular writings about the crisis, ${ }^{13}$ but instead is an impressionistic mosaic intended to persuade readers tliat tort victims and evolving tort law are not the causes of the hability crisis. The liability crisis is due to mass harms that are caused by the products and conduct of large, publiclytraded, and multinational corporations. ${ }^{14}$ Mass harms and public risks occur during the organized, planned, and aggressive pursuit of commercial self-interest. The legally sanctioned nature of huge corporate enterprises permits undemocratically imposed risks, avoidance of direct and

11. For examples of most of these criticisms of common law tort, see generally Stephen Sugarman, Taking Advantage of the Torts Crisis, 48 OHIo ST. L.J. 329 (1987) [hereinafter Sugarman, Taking Advantage]; Issues in Tort Reform, 48 OHIo ST. L.J. 317 (1987) (Symposium). For a further elaboration of all these criticisms and responses, see infra notes 17-26 and accompanying text.

12. Corporations' creations of risks and impositions of harm have overburdened and outpaced the capacity of the legal system. For a discussion of the amount of litigation attributable to corporate harm-causing products, see infra note 18. I am arguing for a rethinking of corporate power and its structures and against our acceptance of their violence and destruction as an imevitable by-product of progress.

13. For an example of such a critique, see Mark Hager, Civil Compensation and Its Discontents: A Response to Huber, 42 StAN. L. REV. 301 (1990).

14. Although many of my observations might also be relevant to other incidents of tort harms, I will focus on mass torts caused by large, publicly-held corporations. Characteristics of these mass harms and public risks make the application of special rules appropriate and necessary. The commercial activities and products of corporations that result in mass harms require a separately devised system of common law rules. 
personal responsibility, as well as great imbalances in power and resources between corporations and those injured by corporate conduct.

Part II examines a few structural characteristics of our legal-political system that are more appropriately blamed for the liability crisis than is common law tort. In particular, I illustrate how adherence to the public/private and the individual/collective dichotomies disables the law from effectively dealing witl corporations and their harm-causing activities. I also concentrate on how our political-legal system is foiled by its singular focus on monetizing and commodifying injury, responsibility, and justice. These structural features have infected mass tort law and fueled the liability crisis. I argue that because these flaws are not caused by or attributable to tort law, critics' proposed changes in tort law will not eradicate the liability crisis. We must look more deeply into our legal and political structures and value systems.

In Part III, I propose solutions to some of the structural mjustices of contemporary mass tort hitigation that can be immediately implemented. Part III explores the double sacrifice that our society and its common law tort system exacts from injured persons. Mass tort victimis inust bear the burdens of their injuries, as well as bear the burdens of proof and economic loss from their injuries prior to judgment and/or settlement. I attribute some of this imjustice to the legal system's failure to attend openly to the power inequalities between mass tort victims and corporate harm-causers. The tort system must assess and coinpensate for power differentials between parties to mass tort hitigation. Relying on feminist theory to understand what power-equalizing or power-balancing might mean, and also to reinterpret disempowering legal rletoric such as "equality before the law," I suggest that because courts are invested witl the state's autliority to mete out justice, courts are warranted in balancing or leveling the power between parties in litigation settings. I propose that courts change the current legal presumptions that inappropriately place both the imitial economic loss and the burden of proof on a party mjured by a large corporate enterprise pursuing private benefits. Courts should allocate burdens and presumptions in a inanner that would empower previously unprivileged parties and make it a fairer contest between disputants in court.

In Part IV, I recommend a reconceptualization of responsibility in tort, and particularly in mass tort law. The new meaning of legal responsibility that I propose is grounded in feminist theories' concepts of care, response, and interdependency. Accordingly, monetary payments to injured parties ought not fulfill legal responsibilities. We must turn our attention to the crafting of remedies that meet the needs of mass tort 
victims and that require harm-causers to satisfy their responsibilities by doing interpersonal caregiving tasks. ${ }^{15}$

My underlying goal is to urge a paradigm shift in how the legal system values and responds to mjured human beings; to examine how laws implement our values of health, safety, human relationships, and well-being; to demonstrate how the judicial system can empower all of us (not just a privileged few); and to scrutinize how the legal system deals with large, for-profit corporate entities. Anecdotal evidence and my personal experiences convince me that in the face of a real, immutable choice, most human beings value their own and their family's health, safety, interpersonal relationships, and enviroument more than they value accumulated wealth, convenience, and the business climate. ${ }^{16}$ Yet tort law and our legal system, by responding in a language of dollars, efficiency, and economic progress, imphicitly privileges econormic ends over relationships, environment, safety, and hnman health. It is not surprising that a system which deviates so significantly from our basic human needs and values is in crisis. Before we can solve the hability crisis, we must make our legal system consistent with our chosen personal values and priorities. We err if we inaintain two sets of valuesone for our personal relationships and one for our activities in the business world. This Article is an exphicit moral and political challenge to our legal system and its participants. It is a call for each of us to take more personal responsibility for one another, our actions and decisions, values, justice system, and forms of social, pohtical, and econormic organization.

\section{Blaming the Victim: Faulting Common LaW TORT AND TORT PLAINTIFFS FOR THE LIABILITY CRISIS}

Criticisms of the tort system abound. ${ }^{17}$ Tort plaintiffs are criticized for their greed and hitigiousness in seeking exorbitant recoveries and for

15. For a synopsis of the ideas in Parts III and IV, see Leslie Bender, Changing the Values in Tort Law, 25 Tulsa L.J. 759 (1990).

16. The frequency and ways in which people opt for health and safety risks and make clioices about personal risk-taking may tell us more about luman incapacity to understand or imagine one's own vulnerability to serious injury or death than about autonomy and free clioice. A decision to rely on luck to avoid mjury is not the same as a decision to accept the risk or the injury itself.

17. For some general critiques of the current model of mass tort litigation, see KENNETH Abraham, Distributing Risk: Insurance, Legal. Theory, and Public Policy (1986) [heremafter K. Abraham, Distributing Risk]; PETER Huber, LiabilitTy: The Legal Revolution and Its Consequences 3-18 (1988) [heremafter P. Huber, Liabil tTy]; Stephen Sugarman, DoIng Away With Personal InJURy LaW: New Compensation Mechanisms for Victims, CONSUMERS, AND Business (1989) [hereinafter S. Sugarman, Personal InJury Law]; Keimeth Abraham, Environmental Liability and the Limits of Insurance, 88 CoLUM. L. REv. 942 (1988) [hereinafter Abraham, Environmental Liability]; Kenneth Feinberg, The Toxic Tort Litigation Crisis: 
incapacitating the civil justice systein by too inany lawsuits. ${ }^{18}$ Juries are criticized for awarding excessive, inappropriate, and inconsistent ver-

Conceptual Problems and Proposed Solutions, 24 Hous. L. Rev. 155 (1987); Peter Huber, Safety and the Second Best: The Hazards of Public Risk Management in the Courts, 85 ColUM. L. REv. 277 (1985) [hereinafter Huber, Second Best]; George Priest, The Current Insurance Crisis and Modern Tort Law, 96 Yale L.J. 1521 (1987); Alvin Rubin, Mass Torts and Litigation Disasters, 20 GA. L. REV. 429 (1986). Some tort scholars caution against discarding our tort system for mass torts. See, e.g., Jean Love, Actions for Non-Physical Harm: The Relationship Between the Tort System and NoFoult Compensation (With an Emphasis on Worker's Compensation), 73 CALIF. L. REv. 857 (1985); Robert Rabim, Environmental Liability and the Tort System, 24 Hous. L. REv. 27 (1987).

Much of the criticisin of common law tort has followed the law's attempts to contend with problems of products liability, mass torts, and toxic torts. These problems seein to defy the capacity of the legal system to respond: the number of victims are astounding and their locations widespread; the kinds of harms are often of a different nature from isolated, single-event incidents of negligence (such as car accidents) in that they exhibit long latency periods and pose the threat of inter-generational harms; defendants often are intricate, nearly impenetrable organizational structures; the science and technology involved in causing these harms and attributing harms to these causes is enormously complex; and the burdens on the judicial system and delays in coinpleting the hitigation process are unfathomable. This list is far from exhaustive, but certainly representative.

18. Enpirical studies of case filings indieate that there has been a substantial increase in products liability and tort cases, but evidence shows that most of the increase is due to the extraordinary number of lawsurits in a handful of cases of corporate mass torts, such as those torts caused by asbestos, Dalkon Shield, DES, Bendeetin, and Agent Orange. Approximately 24,000 claimants had filed lawsuits for asbestos-related injuries as of March 1983, and there are estinates that within 30 years there will be about 200,000 more. JAmes Kakalik, Patricia EeEnER, William FelSTINER, GuS HAGgSTROM \& Michael SHANLEy, VARIATION IN ASBESTOS LITIGATION COMPENSATION AND EXPENSES 3-4 (Rand Institute for Civil Justice, R-3042-ICJ, 1984) [hereinafter J. KAKALIK, ASBESTOS LITIGATION]. A subsequent Rand Report claimed that there were already at least 87,000 asbestos plaintiffs in state and federal courts and that new claims are being filed at a rate of 1,300 per month. MARK PETERSON \& MOLIY SELVIN, RESOLUTION OF MASS TORTS: TOWARD a Framework for Evaluation of AGgregative Procedures 5 \& n.10 (Rand Institute for Civil Justice, N-2805-ICJ, 1988). Dalkon Shield cases are estimated at 325,000; Agent Orange at 250,000, and DES at 1000. Id. at 6. Merrill Dow attorney Alfred Schretter estimates that 1,925 Bendectin claims have been filed world-wide. Rorie Sherman, Bendectin Claims Run Into a Wall, Nat'1 L.J., 1 May 7, 1990, at 1, col. 1.

How can we attribute this phenomenon to the injured victims when the real problein is that there are so many people who are injured by one product or one corporation? If those products had injured only one person each, then we would not claim those single victims were overly hitigious for bringing lawsuits to recover for their injuries.

Complaints about bitigiousness and excessive verdicts are suspect because many victims of tortious conduct do not sue at all. Richard Abel, The Real Tort Crisis-Too Few Claims, 48 OHio ST. L.J. 448-52 (1987) [hereinafter Abel, Too Few Claims] (empirical analysis indieating many injuries fail to claim). See also Patricia Danzon, Medical Malpractice: Theory, Evidence, AND Public Policy 18-29 (1985) (discussing infrequency of inedieal malpractice claims in relation to injuries inflicted by negligent inedieal care); Marc Galanter, Beyond the Litigation Panic, in NEw Directions IN LiabiLITY LAW 18-30 (W. Olson ed. 1988). Kristin Bumiller notes that only a few people who believe they have experienced illegal discrimination based on "race, age, sex, handicaps, umion membership, or other things" ever pursue a legal reinedy at all. KRISTIN BUMILLER, THE CrVIL RioHrs SOCIETY 26 (1988). She attributes this to an ideology of victimization that legitimizes the "victim's" own defeat. Id. at 28-29. Bumiller notes that victims of discrimination "feel that asserting their legal rights would not enable thein to express their sense of dignity but would force them to justify their worthiness against a more powerfnl opponent." Id. at 109. Perhaps inass tort victims feel the same way. 
dicts. ${ }^{19}$ Critics bemoan that joint liability lias been wrongfully employed to help plaintiffs find deep pockets or to impose a regime of collective guilt, which counters our ethic of individualism and responsibility. ${ }^{20}$ Some critics claim that causation doctrine has been distorted to impose liability in situations in which there is no clear connection between the mjury and the liarm. ${ }^{21}$ Otler critics blaine the evolution of tort law (e.g.,

Many plaintiffs settle their cases for undisclosed amounts or small amounts per victim. For example, although the Agent Orange litigation ended with a $\$ 180$ million settlement, it is estimated that each long-term disabled veteran will get only an average of $\$ 5700$ and the average survivor's benefit will be $\$ 1800$. Robert Rabin, Tort System on Trial: The Burden of Mass Toxics Litigation, 98 YALE L.J. 813, 818 (1989). One commentator relates, a "woman testified that the damage to her daughter alone wonld amount to approximately $\$ 6.6$ million, thus leading ler to remark that, 'I realize that we are in need of a miracle of the loaves and fishes if we only have $\$ 180$ million.'" Michael Riccuili, Equity and Accountability in the Reform of Settlement Procedurcs in Mass Tort Cases: The Ethical Duty to Consult, 1 Geo. J. LeGAl ETHucs 817, 859 (1988) (quoting In re Agent Orange Prod. Liab. Litig., 597 F. Supp. 740, 768 (1984), aff'd, 818 F.2d 145 (2d Cir. 1987), cert. denied, 484 U.S. 1004 (1988)).

Certainly there are exceptional cases where the verdicts do seem outlandish or highly inconsistent, but those unique and relatively rare cases have been presented and prostituted by the inedia and tort critics in their lobbying for tort reform as normal and predictable results of our current tort rules. Abel, Too Few Claims, supra, at 445.

19. For a discussion of excessive and unnecessary compensations in tort claims, see $S$. Sugarman, Personal INJURY LAw, supra note 17, at 37-39. If mass tort verdicts are disproportionately high (which is arguable), then there mnst be a reason. Defendants and their attorneys are afforded fair and ample opportunities to argue to juries about just resolutions and amounts of recovery. Perhaps jury decisions in favor of plaintiffs and the amounts of recovery refiect a sense of social outrage at the injustices and unconsented risks suffered by mass tort victims, or compassion for those who bear these leinous injuries as losers in a utilitarian calculation not of their own making. If soinething about the kinds, circumstances, and extent of these larms evokes these responses from juries, then we should listen to that message rather than try to eliminate their response. If juries award punitive damages, then it is because they recognize the appropriateness of pumishment. Corporate defendants argue that they cannot survive when subjected to these multiple lawsuits and high verdicts. A solution to multiple, large verdicts against corporate defendants is to stop corporations from causing mass harms, rather than preventing juries from doing what they can to reinedy injustices they perceive.

20. See, eg., Abraham, Dilemma of Mass Tort, supra note 4, at 847 (traditional concepts of individnal responsibility are being called into question by conceptions that overlook differences between individual parties and thereby proinote more collective forms of responsibility). Blaming tort law for the development of new joint and several liability theories that lave adapted to changing realities of how corporations conduct busimess in this country is also inappropriate. In a society of mass production, mass distribution, mass marketing, and relatively fungible products (or at least products creating relatively fungible risks to the public), liability rules ought to reflect reality. Tort law's ability to respond to these changes in our society is reason for praise, not condemnation. If we do not like our economic organization and material production, then we ought to change them, rather than condemn tort law.

21. See, eg., P. HUBER, LIABILITY, supra note 17, at 16. In wrestling with wide-spread harms, unusual configurations of causal information, and blurred identities of harm-causing corporate entities, courts lave proposed alternative methods for proving causation and attributing liability. These theories melude: 1) market share liability and alternative hability, see Hymowitz v. Eli Lilly, 73 N.Y.2d 487, 539 N.E.2d 1069, 541 N.Y.S.2d 941, cert. denied, 110 S. Ct. 350 (1989); 2) weak preponderance of evidence standards, see In re Agent Orange, 597 F. Supp. 740, $833-39$ (E.D.N.Y. 1984); and 3) substantial factor tests, see Elam v. Alcolac, 765 S.W.2d 42, 175-85 (Mo. Ct. App. 
discovery rules that extend the limitations periods, strict liability for products and abnormally dangerous activities, alterations in proof of causation) for the unavailability of liability insurance. ${ }^{22}$ Transaction costsattorneys' fees, litigation and administrative expenses-often exceed the compensation that goes to injured plaintiffs. ${ }^{23}$ Judges are criticized for

1988), cert. denied, 110 S. Ct. 69 (1989). For theories of environmental or ecological causes based on epidemiological studies and statistical probabilities, see Sterling v. Velsicol Chem. Corp., $647 \mathrm{~F}$. Supp. 303, 321-22 (W.D. Tenn. 1986), aff'd in part, rev'd in part, 855 F.2d 1188 (6th Cir. 1988).

Vicarious corporate responsibility for mass harms represents more than a search for the deep pocket. Theories of vicarious corporate responsibility acknowledge the relationship between the power to control and decide, and the harms caused by facilities or persons subordinated to that power. Joint liability imposed on corporations in the DES litigation context reflects a community sense of collective corporate responsibility, when products by different corporate producers create very similar risks and harms. In this way, tort law gradually is adapting to circumstances of indeter. minate defendants and indeterminate plaintiffs. These changes include newer uses of statistics, probability theory, and different burdens of proof and persuasion that correlate with the kinds of harms and risks that corporations have created and imposed on the public. Tort law expansion indicates a belief that corporations should not be able to relieve theinselves of hability just because our level of scientific sophistication does not allow us to articulate the causal connection between actual harms and corporate-imposed risks in the same manner that we can for car accidents or shipand-fall cases. In many ways we are searching for a new paradigm of legal cause for mass, toxic, and corporate harms comparable to the ehange in plysics from Newton to Einstein to Heisenberg.

22. See, eg., Abraham, Environmental Liability, supra note 17, at 955-56 (expansion of environmental tort liability will place enormous burdens upon insurance underwriters and reduce availability of insurance); Priest, supra note 17, at 1538-39 (expansion of modern tort hability has led to the reduction of insurance availability).

23. For critiques of excessive transaction cost, see Eli BERNZwEIG, By ACcIDENT, Not DESIGN: The CASE for CoMprehensive INJURy Reparations (1980); DeEoraH HeNSLER, WIL. liam Felstiner, Molly Selvin \& Patricia Ebener, asbestos in the Courts: The Challenge of Mass Toxic TORTS (Rand Corp. Study, R-3324-ICJ, 1985); J. KaKaldK, AsbesTOS LITIGATION, supra note 18; JAMES KaKaliK \& NichOlas PACE, COSTS AND COMPENSATION Paid in Tort Litigation (Rand Corp. Study, R-3391-ICJ, 1986); JAmes Kakalik \& Abby Robyn, Costs of the Civil Justice System: Court expenditures for Processing Tort CASES (Rand Corp. Study, R-2888-ICJ, 1982); JAMES KaKalIK \& RANDY Ross, CosTS OF THE

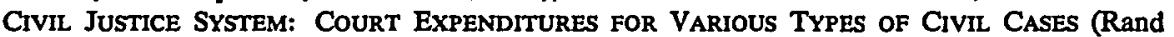
Corp. Study, R-2985-ICJ, 1983); Stephen Sugarman, Doing Away with Tort Law, 73 CALIF. L. REV. 555 (1985) [hereinafter Sugarman, Tort Law].

The breakdown of the transaction cost statistics in tort litigation is astounding. According to one study:

In 1985, the total expenditure nationwide for tort hitigation terminated in state and federal courts of general jurisdiction was between $\$ 29$ and $\$ 36$ billion. This accounts for approximately 92 percent of all compensation paid in tort litigation. Of that total, $\$ 16$ to $\$ 19$ billion was spent for the various costs of the tort litigation system, not including the net compensation paid to plaintiffs. Plaintiffs were paid $\$ 21$ to $\$ 25$ billion in total compensation. After deducting their legal fees and expenses, which on average annount to about 30 percent of the total compensation, and the value of their time, they netted $\$ 14$ to $\$ 16$ billion in compensation. Defendants' legal fees and expenses totaled about $\$ 4.7$ to $\$ 5.7$ billion.

Deborah Hensler, Mary Vaiana, James Kakalik \& Mark Peterson, Trends in Tort LITIGATION: THE STORY BEHIND THE STATISTICS 26 (Rand Corp. Study, R-3583-ICJ, 1987) (footnotes omitted). Many people justifiably would argue that too large a part of the enormous expense of tort litigation is the fee paid to lawyers. A Rand Report about the cost of civil litigation revealed that $57 \%$ of the expenses of bitigation in non-auto tort litigation are for expenses other than plaintiff 
legislating or exceeding their judicial roles when they innovate to find just resolutions of grievous mass tort harms. ${ }^{24}$ There are criticisins that the utilization of strict hability in mass torts is coercive and operates as an unjust tax. ${ }^{25}$ Critics argue that the nexus between tort law and its traditionally expressed goals is threadbare. ${ }^{26}$ Many of these critics, at a minimum, imply that common law tort rules and verdicts cause and continue to perpetuate these problems. They further imply that these rules and verdicts have created the perceived liability crisis.

Like mass tort victims and common law tort itself, rape and domestic violence victims often are blamed for the injuries they suffer-they did something wrong or did not say "no" loudly or frequently enough.27 Rape and doinestic battering are legally constructed as private disputes between two parties, rather than as social and political problems. Rape is about inale violence, domination, sexuality, and cultural, social, and political conditions of sexism. Analogously, mass torts are not private disputes. Mass torts are about corporate violence, power, irresponsibility, and cultural, social, and political conditions that ultimately prioritize wealth and production over human welfare. Blaming cominon law tort for the hability crisis is like blaming woinen for being raped. ${ }^{28}$ We must

compensation. Hensler, supra note 4, at 493 (pie chart illustrating allocation of non-auto tort litigation expenditures in 1985).

24. For an account of the criticisms of Chief Justice Rose Bird, Justices Grodin, and Reynoso of the California Supreme Court for their innovations in products liability, see Sugarman, Taking Advantage, supra note 11, at 338 n.52. Ethies complaints were filed against Chief Judge Miles Lord in the Dalkon Shield Litigation. See In re A.H. Robins, JCP 84-001 and JCP 84-002 (8th Cir. Judicial Council, Dec. 26, 1984); Gardiner v. A.H. Robins Co., 747 F.2d 1180, 1190 (8th Cir. 1984). For criticisins of Judge Jack Weinstein in the Agent Orange litigation, see PETER ScHUCK, AGENT Orange on Trial: Mass Toxic Disasters in tHe Court 160-61, 222-23 (1987).

25. See P. HUBer, Liability, supra note 17 , at 3-18.

26. See S. Sugarman, Personal InJury Law, supra note 17, at 3-74.

27. See MeNAchem AMIR, PATterns IN Forcible RAPE 259-76 (1971) ("victim-precipitated rape"); SUSAN BRowNMILLER, AGAINST OUR WILL: MEN, WOMEN AND RAPE 312 (1975); RoseMARIE TONG, WOMEN, SEX, AND THE LAW 102 (1984); Christine Littleton, Women's Experience and the Problem of Transition: Perspectives on Male Battering of Women, 1989 U. CHI. L. F. 23, 2829. I rccognize that my analogy to rape is a bit strained. I argue that both tort law and tort victims are "victims" in the sense that they are blamed for the liability crisis; in contrast, I argue that only rape victims (and not rape laws) are blamed for the harms done to them. Tort critics blaine both the victims and the legal rules that permit suing for damages for a crisis in the judicial, insurance, and business systems. Because of the manner in which the critics lave constructed the problem, it is necessary to include both imjured persons and tort law in the category of "victim." Rape laws, in contrast, are not generally blamed for the initial harm that rape victims suffer, although it is rccognized that the construction of rape law and requirements for proof of a rape case can add to the harm that rape survivors suffer by causing thein to be "raped" a second time by the legal systen. See Catharine Mackinnon, Feminism Unmodified: Discourses on Life and Law 82 (1987).

28. For an example of blaming rape victims, see, e.g., Rape Guilty Plea, After Acquittal, N.Y. Tunes, Dec. 7, 1989, at B21, col. 6 (quoting Fort Lauderdale, Broward County, Florida jury foreman as saying, "We all feel she asked for it the way she was dressed"). 
focus on eradicating inale violence and correcting sexism to eliminate rape; likewise, we must focus on abolishing corporate violence and revising corporate organization and power to eliminate inass torts. ${ }^{29}$

Suspending the availability of tort remedies and tort law for victims of mass torts would ouly exacerbate the probleins. ${ }^{30}$ It would be like eliminating women's ability to cliarge men witl rape. The needs of the victims for justice, recognition of their harms, empowerment, retribution, and compassionate responses from the community would not be met by closing off access to courts, even if there is a substitution of an administrative compensation system. ${ }^{31}$ Nor would there be an adequate clieck on a corporation's freedom to impose undemocratic risks on others so long as it could provide "compensation." Courts and the common law can serve important roles in tempering abuses of corporate power. We need a solution to the liability crisis that will put an end to allowing corporations to impair health or safety in exchange for advancing economic well-being or by paying monetary damages.

There can be little doubt about the parallels between the relationships of power that privilege men in the law of rape, (and blaine the victim for her own injuries), and those power relations that privilege corporations (and blame victims for injuries or the probleins created for the "business chinate" when pursuing legal remedies for their injuries). In both cases, men and corporations have had more power than their "vic-

29. For just a few examples of corporate conduct and violence that have led to mass tort or toxic harms, see Elam v. Alcolac, Inc., 765 S.W.2d 42 (Mo. Ct. App. 1988) ("state of the art" chemical plant with environmental controls managed by uneducated jaritor and cost-based rejections of necessary environmental improvements causing physical injuries and chemically-induced immune deficiencies in neighbors), cert denied, 110 S. Ct. 69 (1989); PAUL Brodeur, OUTrAGEOUS MisconduCT: THE ASBESTOS INDUSTRY ON TRIAL (1985) (exposure to asbestos manufactured by Johns-Manville leading to asbestosis, inesothehiona and lung cancers); Matt Tallmer, Chemical Dumping as a Corporate Way of Life, in Corporate VIolencE: INJURY AND DEATH FOR PROFIT 111 (S. Hills ed. 1987) (Love Canal, Occidental Chemical Company at Lathrop, California; Bloody Run Creek, New York; Bethpage and Hicksville, Long Island; and nore); Miles Lord, The Dalkon Shield Litigation: Revised Annotated Reprimand by Chief Judge Miles W. Lord, 9 HAMLINE L. REV. 7 (1986) (A.H. Robins IUD with defectively designed tail-string that caused deaths, abortions, injured infants, infertility, pelvic inflammatory disease and other imjuries). For similar accounts, see Stuart Hills, Corporate Violence: INJURY AND DeATH For Profit (1987).

30. Many critics have sought various kinds of administrative compensation scheines in heu of common law tort remedies for inass tort victims. See S. Sugarman, Personal InJury Law, supra note 17; Troyen Breunan, Causal Chains and Statistical Links: The Role of Scientific Uncertainty in Hazardous-Substance Litigation. 73 CORNELL L. REv. 469 (1988); Kenneth Feinberg, The Toxic Tort Litigation Crisis: Conceptual Problems and Proposed Solutions, 24 Hous. L. Rev. 155 (1987); William Ginsberg \& Lois Weiss, Common Law Liability for Toxic Torts: A Phantom Remedy, 9 Horstra L. Rev. 859 (1981); Jeffrey Trauberman, Statutory Reform of "Toxic Torts": Relieving Legal, Scientific and Economic Burdens on the Chemical Victim, 7 HARv. ENVTL. L. REv. 177 (1983).

31. See, e.g., Stanley Ingber, Rethinking Intangible Injuries: A Focus on Remedy, 73 CALIF. L. REv. 772, 772 (1985) (discussing needs of victims). 
tims" to influence the structure, analyses, categories, and definitions used by the legal system to define and resolve disputes. In both cases, powerful men and corporations have influenced the legal system and cultural understandings to try to prevent women and imjured persons from holding them publicly responsible for the consequences of their rapes and corporate, profit-motivated harms.

When critics assail the tort system, they are blaming the tort system for consequences more correctly attributed to the enormous quantities of harm caused by corporate violence and corporate risk-imposition. No wonder the legal system's back is breaking under this additional weight. ${ }^{32}$ There are many problems with the common law tort system and we inay be in the throes of a "hiability crisis," but the tort critics' focus is misplaced. The problems are not rooted in our tort system, but merely reflected by it. The source of the "hiability crisis" lies im our economic and value structures.

First, in the name of economic efficiency, progress, and advanced technology, we liave licensed-intentionally or inattentively-massive corporate organizations that are as great im size, wealtli, and power as nation-states. Yet we permit them to function witliout the power checks ordinarily imposed on our traditional, collective pohtical institutions. ${ }^{33}$

32. The common law tort system originally developed to resolve problems between two persons, a plaintiff and a defendant, who collided in the course of their daily living. Our collective experiences taught us that this model proved woefully inadequate in certain situations. This madequacy was particularly apparent in the business or work world, where injuries were an accepted price for advanced industry and "progress." Despite our social-political decision to substitute statutory workers' compensation programs for negligence actions, the model of individuals colliding lias been retained, for the inost part, as the pattern for products liability, toxic and mass tort litigatiou.

Oue of the problems of common law tort is that it equates the rules and problem-solving meehanisms designed to settle car-accident type events with mass torts situations that involve risks and liarms to many victims-risks that are caused by complex organizations in pursuit of commercial advantage. These events are too different to be treated alike. Courts lave developed alternative theories to respond to the unique nature of products liability and mass harms, but these theories lave been blained for the "liability crisis." See, e.g., Sindell v. Abbott Laboratories, 26 Cal. 3d 588, 611-13, 607 P.2d 924, 936-38, 163 Cal. Rptr. 132, 145-46 (development of market-share hability theory), cert. denied, 449 U.S. 912 (1980); Barker v. Lull Eng'g Co., 20 Cal. 3d 413, 432, 573 P.2d 443, 455-56, 143 Cal. Rptr. 225, 237-38 (1978) (altering burdens of proof to compensate for disparities in the accessibility of infornation about design defects); Greenman v. Yuba Power Prods., 59 Cal. 2d 57, 62, 377 P.2d 897, 900, 27 Cal. Rptr. 697, 700 (1962) (developing strict hability in tort for defective products); Beshada v. Johns-Manville Prods., 90 N.J. 191, 201, 447 A.2d 539, 545 (1982) (refusing to pernit a "state-of-tle-art" defense in strict products liability claim).

33. In the United States, we clain to believe in direct democratic participation or at least representative democracy. One tenet of this political ideology is that our government processes and decisionmaking are open to public scrutiny. We could probably solve some of the liability crisis if, in accord with our ideological tenets of government, we open the bellies of large organizational beasts to expose to the public any and all of the information about risks, experiments, research, development, complaints, and harms-information that is now lidden and in corporations' exclusive control. Mass harms are attributable in part to the secrecy and maccessibility of corporate information 
The enormous range of harms that large corporate entities cause directly correlates with the power of corporations to coordinate their workforce and their ability to mass produce and mass distribute products. ${ }^{34}$ The seeds of the liability crisis can be found in the law's protection of corporations' ability to impose risks, not the law's response to tort victims.

Second, the liability crisis lias grown out of a misapplied value system that wins our consent by claiming to prefer values of safety, health, and hife over property, but ultimately prioritizes efficiency and progress. Despite our legal system's rhetorical endorsement of safety, liealth, and liuman dignity, liuman mjuries and deaths are translated into economic values to be calculated in determining policies and preferred legal principles. We rely on our articulated values to prevent these harms from liappening in the first instance. When harms do occur-and we find that we are not protected as we thought we were-we again rely on the prioritized values of liealtli, safety, and human dignity to give us fair remedies through the legal process. This gap between our ideological beliefs and our practices stimulates the hability crisis.

and the absence of a public voice in the intelligent assessinent of risks. For evidence of concealed information and dilatory and deceptive discovery practices by corporate defendants in mass torts cases, see RusSell MoKhiber, CoRporate CRIME AND VIOLENCE $277-87$ (1988). Mokhiber cites Johns-Manville's policy of refusing to advise workers of asbestos related risks as one example of corporate concealinent. According to Johns-Manville's medical director, Kenneth Smith,

[A]s long as the man is not disabled, it is felt that he should not be told of his condition so that he can live and work in peace and the Company can benefit by his many years of experience. Should the man be told of his condition today, there is a very definite possibility that he would become inentally and physically ill, simply through the knowledge that he has asbestosis.

Id. at 283-84. See also Anderson v. Beatrice Foods Co., 900 F.2d 388 (1st Cir.) (affirming district court's finding of "overwhelming evidence" of discovery inisconduct during the Anderson v. W.R. Grace litigation), cert. denied, 111 S. Ct. 233 (1990); Borel v. Fibreboard Paper Prods., 493 F.2d 1076, 1106 (5th Cir. 1973) (relationship between asbestos and lung disease established more than sixty years ago, yet management gave little or no warnings to employees), cert. denied, 419 U.S. 869

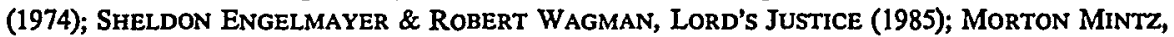
AT ANy COST: CoRporate GREed, Women, AND THE DALKon ShIEld (1985); Lord, supra note 29 , at 10 (corporation suppressed information about harms from multifilamented tailstring and delayed recall).

34. Without the collective actions of members of the corporate enterprise working together, unass harms would not follow. Individuals working alone cannot usually cause the magnitude of destruction, risk, and harm that corporations cause by combining the planning, strategies, energies, and work of unany employees. See M. Peterson \& M. Selvin, supra note 18, at 3-12 (discussing several examples of inass accidents and probleins in ensuing litigation). Sometimes the collective activity goes beyond a single corporation to unultiple corporations acting in parallel to produee fungible or relatively generic products. See, eg., In re Agent Orange Prod. Liab. Litig., 597 F. Supp. 740 (E.D. N.Y. 1984), aff'd, 818 F.2d 145 (2d Cir.) (producers of seven major chemical company producers of Agent Orange were mixed together before being applied in Vietnam), cert. denied, 484 U.S. 1004 (1987); Sindell v. Abbot Laboratories, 26 Cal. 3d 588, 608 P.2d 924, 163 Cal. Rptr. 132 (over 200 produccrs of diethylstilbestrol), cert. denied, 449 U.S. 912 (1980). 
Third, I also claim that our legal system imterprets justice as monetary compensation for harms (achieved through win/lose resolutions of rights conflicts). This limited notion of justice has also precipitated the hability crisis. A richer construct of justice would include compassion, caring, and responses to particularized imjured victims' needs, and would grow out of principles of substantive equality before the law. Our civil justice system articulates a concern for mass tort victims and equality, but that rhetoric is often shallow or trumped by the structure of the legal system that privileges corporations in the hitigation arena. A corporation's privileges are reflected in many ways-presumptive non-hability, access to legal services, familiarity with the system, pohtical wealth and power-but I am particularly interested in the placement of presumptions and burdens of proof. The hability crisis is partially a function of how our legal system fails to respond to power differences between parties in hitigation, not a function of anything peculiar to common law tort that can be eradicated through tort reform legislation or statutory compensation systems.

Fourth, the hability crisis results from our legal system's mconsistency in holding corporate decisioumakers legally responsible for corporate harms $\mathrm{s}^{35}$ and, more importantly, its failure to make corporate actors personally responsible in a caregiving way ${ }^{36}$ for the harms they have created through their corporate actions. This agam is a problem with our legal and pohtical structure that permits massive, private, for-profit corporate enterprises to imsulate individuals from personal responsibility for their decisions and conduct, not a problem with common law tort.

And last, but not least, we have failed to create adequate public forums, other than tort lawsuits in courtrooms, for citizens to express their

35. The collective activity within a corporation works to buffer individuals from individual responsibility for imposed risks and harms. See MeIr DAN-CoHEN, Rights, Persons ANd ORgaNizations: A Legal Theory for BuREaUCratic SOCIETY (1986); Christopher Stone, Where The Law ENDS: The Social Control of Corporate Behavior 111-18 (1975); Kathleen Brickey, Rethinking Corporate Liability Under the Model Penal Code, 19 RuTGERS L.J. 593 (1988); John Coffee, "No Soul to Damn: No Body to Kick": An Unscandalized Inquiry into the Problem of Corporate Punishment, 79 Mrch. L. REv. 386, 393-400 (1981); Eliezer Lederman, Criminal Law, Perpetrator and Corporation: Rethinking a Complex Triangle, 76 J. CRIM. L. \& CRIMINoLOGY 285 (1985); Michael Metzger, Organizations and the Law, 25 AM. BUS. L.J. 407, 410 (1987); Christopher Stone, The Place of Enterprise Liability in the Control of Corporate Conduct, 90 YALE L.J. 1, 11-29 (1980). Development of collective, corporate liability is a predictable consequence of a legal systen that permits large, complex, opaque corporate structures to shield individuals from responsibilities. Complex corporate structures, combined with the phenomenon of liability insurance, tend to shield decisionmakers and corporate actors, as well as slareliolders and other persons who benefit from corporate actions, from any sense of personal responsibility for their acts. Tort law did not create multi-layered organizational structures that divide tasks into unintegrated, component parts so that no one (or hardly anyone) knows the full picture of what is being done.

36. See infra Part IV, notes $134-76$ and accompanying text. 
outrage at the injurious imposition of unconsented-to risks. Only in the courtroom can citizens officially and publicly call corporations and their officials to answer for their actions, prevent corporate harm-causers from evading public government criticism and lawsuits, expose corporate decisionmaking and publicly reprimand corporations and their decisionmakers for the harms they cause. Only in the courtroom do we acknowledge and reinstate the dignity, respect, and autonoiny of the injured victims in a public way. Tort litigation provides a place for victims to tell their stories to the public and make the perpetrators listen. Tort law theoretically empowers injured victims to act, when the government does not protect their health and safety. We shonld not blame injured victims for utilizing the tort system as this kind of public forum, nor fault the tort system for providing it. We should praise common law tort for its tenacity, particularly in an era of bad press, lax regulatory agencies, and minimal criminal sanctions. The failures here are in the background politieal and legal systems, not in common law tort or with its victims.

The "hability crisis" is a symptom of a systemic disease in our body pohtic. Common law tort has been construed wrongly as the disease, sustaining our beliefs that if it is surgically removed or treated, then the body will heal. It is time to correct this serious imisattribution of blame and seek out the appropriate sources for our condenmation. We must stop the eounter-productive blaming of tort law for these symptorns and examine what elements of our entire legal system and our culture have caused this "hability crisis."

We should not blame the tort system for responding to the problein of mass harms when little has been done to stop those harms from occurring. Our legal system perimits corporate organizations to impose risks on others, accnmulate limitless wealth, decide policy undemocratically, and produce and distribute products world-wide. It has given us little else with which to work. Because we perimit these corporate behaviors and structures, and because we have designed no other way to compensate victims (monetarily or nonmonetarily), we need common law tort. It compensates, and it provides foruns for public debate about the imposition of risks. We need a way to publicly deter harmful conduct, expose and shame inass harm-causers, and to provide for public debate about the imposition of these risks by private corporations upon the public. Tort law may fail to meet all these needs simnltaneously, but given the difficulty of that task, we ought not blame the law. Instead, we sliould criticize the social-political system for the burden that, by default, it imposes on the common law tort system.

I certainly am not arguing that common law tort is fine the way it is. For starters, we could all agree that tort litigation is too expensive and 
slow. In this Article, I suggest basic changes in tort law that might improve soine of its flaws. But I oppose critics who call for the abolition of common law tort and the exclusive substitution of statutory compensation systems, neo-contractual systems, or ones based on technocracies. ${ }^{37}$ We must preserve the power of injured individuals to resort to the courthouse for rehef. While correcting problems with the tort system, we should not throw out the baby with the bath water. ${ }^{38}$

We cannot eliminate rape or domestic violence by blaming the victim. We must address problems of male violence and the conditions of our culture that foster male domination. Similarly, we cannot eliminate the "hability crisis" by blaming tort victimis or abohishing tort law. We must condemn corporate violence and the economic, social, and political conditions that have permitted corporate dommation. The solution is not to cap damages (economic, non-econornic, and punitive), attack jury verdicts, or eliminate joint and several hability. Nor will a solution be achieved by returning to a pure fault-based system, antiquated rules of causation, or proof and definitions of harms developed in a different economic and cultural reality. ${ }^{39}$ We only can eliminate the habihity crisis by eradicating the conditions for mass harms. If we truly inean that health and safety are most important, we inust not permit thein to be part of any economic calculus toward "progress." They must be non-negotiable. If these values are our first priority or our first principle, then we really must begin there and reorganize all else around them. ${ }^{40} \mathrm{~A}$ reorganization of priorities may require us to "bite the bullet" and make difficult sacrifices, but the synchronization of our values with our practices may also dissipate the hability crisis.

37. For an example of these critiques, see S. Sugarman, Personal InJury Law, supra note 17, at 125-210; Richard Epstein, Session One Discussion of Paper By Richard Epstein, University of Chicago, 10 CArdozo L. Rev. 2193, 2223, 2227 (1989) (discussion of Peter Huber, The UniNTENDEd ReVolution IN Product Liability LaW (1988)); Huber, Second Best, supra note 17, at 329-35 (1985); Priest, supra note 17, at 1587-90. See also Peter Bell, Analyzing Tort Law: The Flawed Promise of Neo-Contract, 74 MinN. L. REv. 1177 (1990) (critiquing neocontractual analysis).

38. For a similar use of this metaphor with respect to proposed alterations in joint tortfeasor liability, see Richard Wright, Throwing Out the Baby with the Bathwater: A Reply to Professor Twerski, 22 U.C. DAvis L. REv. 1147 (1989); Aaron Twerski, The Baby Swallowed the Bathwater: $A$ Rejoinder to Professor Wright, 22 U.C. DAvIS L. REv. 1161 (1989).

39. But see Epstein, supra note 37, at 2220-22; Peter Huber, Flypaper Contracts and the Genesis of Modern Tort, 10 CARDozo L. REv. 2263, 2287 (1989).

40. The typical response is that if we were forced to choose, then we would not really want to give up our convenience for safety or improved health. There may be some truth to that if we do not understand the risks to our health (individual, collective, and environmental) as immediate and certain (rather than escapable through luck), and if we do not believe that there can be rcal change. When those factors are accounted for, what we might potentially lose in convenience and "progress" might be gained in improved life and health expectancies. 


\section{General Problems of OUR Legal System That Fuel the LIABILITY CRISIS}

Rather than blame common law tort or tort plaintiffs for the liability crisis, I suggest that we analyze the aspects of our legal system that contribute to mass tort problems. The legal system's false dichotomies of public/private and individual/collective fuel the hability crisis by ignoring the unique nature of corporate activities, decisionmaking, and riskimposition that generate mass harms. These dichotomous ways of viewing the world fail to capture the character of corporate actions, and they impede our thinking about ways the legal system can prevent the mass harms that corporations cause. We must formulate new categories for our legal analysis and end the commodification of justice and responsibility that fans the flames of the hability crisis.

\section{A. Some False Dichotomies: Public/Private and Individual/Collective}

Early in law school, students learn to distingnish between criminal law, which is public law designed to protect society's interests, and tort law, which is private civil law designed to compensate individuals wrongly mjured by another's conduct. ${ }^{41}$ Even if this dichotomous understanding was appropriate when neghigence and personal mjury law first developed, the public/private distinction does not make sense for a legal systein in a society in which large corporate enterprises, pursumg private gam, impose risks on the general public and make social utility decisions affectimg the public at large without public representation.

41. For an overview of the distinction between public law and private law, see Jennifer Nedelsky, Reconceiving Autonomy: Sources, Thoughts and Possibilities, 1 YALE J.L. \& FEMINISM 7, 15-20 (1989). Some commentators have suggested that mass tort might be the appropriate place to bridge the concepts. David Rosenberg, The Causal Connection in Mass Exposure Cases: $A$ "Public Law" Vision of the Tort System, 97 HARV. L. REv. 849, 924-29 (1984). I think it is particularly ironic low many different pairs of meanings have been attributed to the words "public" and "private." The public/private distinction, as used in law, uses the label "public" to refer to tlee government and "private" to refer to the market and individual busmess relations. But the same market that is labeled "private" in the split between public law and private law is called "public" in the split between public and private spheres of activities in which the law/business/market are public and the home is private. See Frances Olsen, The Family and the Market: A Study of Ideology and Legal Reform, 96 HARV. L. REv. 1497, 1501 (1983). In addition, we have more common meamings of "public" and "private" that infiltrate our language. "Public" also lias a meaning that connotes groups of people-as in "the public." "Private," on the other land, seems to involve only an individual or a couple of individuals interacting. Disregard for this third set of meanings for "public" and "private" has comphicated the law of mass tort. Mass tort actions with corporate defendants straddle the fence of pnblic and private and require new categories.

If we continne to use the public/private distinction in law-whicls we probably will at least until some real transformations occur-mass torts must be considered public because they involve the public as a non-differentiated group of people and imvolve activities and conduct that affect the public sphere (busmess/market/law). 
When mass harms are caused by products or activities-such as asbestos, chemical production, hazardous waste disposal, nuclear power, atomic testing, contraceptives and bio-technologies, and environmental/ human disasters-the ensuing legal battles cannot be conceived of as purely private law disputes, even though they do not fit neatly into the class of disputes resolved by public law. Mass tort disputes are not public in the traditional sense that a governmental body is involved $\mathrm{m}$ regulation, control, or im the litigation. Nor are they public in the traditional sense that a public official is authorized to bring suit and to represent society in the vindication of its values or interests. On the other hand, these disputes are not private in their scope of harm or numbers of "victims," their implications about power and decisionmaking in our society, their repercussions as precedents in the legal system, or in their capacities as metapliors for our society. Their names have become symbols of pubhic, social catastrophes-they belong to all of us and represent all of us. ${ }^{42}$

Criminal law is public law because it responds to public harms ${ }^{43}$ and provides remedies for society in general. Traditionally, we have regarded tort law as private law because it seeks judicial remedies for particular victims, ${ }^{44}$ rather than for our society in general. ${ }^{45}$ Damages in inass tort actions are paid to plaimtiffs or victims, not to the state as fines. Mass tort plaintiffs, ratlier than the state, decide whether to initiate legal action, how to construct the case, what to claim, whoin to sue, whether to settle, and whether to continue. But the label "private law" is solely

42. Professor Leon Green made a similar observation about tort law thirty years ago. Leon Green, Tort Law, Public Law in Disguise (pts. 1 \& 2), 38 TEx. L. REv. 1, 257 (1959-1960).

43. Experience and intuition convince ine that mass torts are public harms, to people, to the community, to the economy, in every way that crime is a public harm. Yet placing the tortfeasors (the corporate management and entrepreneurs, the researcli and development scientists, the design, safety and environmental engineers, the sales forces, and marketing experts) in jail as criminalseven if we could locate the responsible parties-would not suffice. Criminal sanctions against corporate offieers would not fully remedy the harms because we would still have to respond to the pliysical, emotional, and interpersonal losses or "costs" inflicted upon particular individuals, and the contiuued, dangerous decisionmaking potential of the errant corporation. Corporate officers or actors are replaceable, yet the corporation lives in perpetuity beyond its connection to particular people. Nor would taking inouetary resources from the corporation as tort damages remedy the problem because corporations can buy insurance to cover these losses or can file for reorganization in bankruptey if they liave created excessive harms. See, e.g., In re A.H. Robins Co., 88 Bankr. 742 (E.D. Va. 1988); In re Johns-Manville Corp., 91 Bankr. 225 (S.D.N.Y. 1988).

44. Criminal punishments also provide "private law" relief by exhibiting social concern for the victim, expressing community outrage at the victim's larm and meeting the victim's need for retribution even though they are classified as "public."

45. As Peter Gabel and Paul Harris said: "One way that the dominant ideology contributes to alienation and powerlessness is by generating a false distinction between public and private life, a distinction that translates collective social problems into individual personal matters." Peter Gabel \& Paul Harris, Building Power and Breaking Images: Critical Legal Theory and the Practice of Law, 11 N.Y.U. REv. L. \& SOC. ChANGE 369, 396 (1982-1983). 
rlietorical because, in fact, mass tort remedies benefit the public as do criminal punishments. Mass tort remedies arguably deter future impositions of risk, indicate social disapproval, ${ }^{46}$ and bear some of the costs for inass catastroplies that otherwise would be borne by tax dollars.

Private and public law are also distinguished by different requireinents about notice and the clarity of standards. Public law standards of conduct and safety are decided and articulated in advance througli legislative enactments and administrative rules and regulations. Specific standards of prohibited conduct in private law are not made explicit im advance of the clioices to act. Criminal law relies on clear rules; private tort law rests on generalized standards of beliavior (like reasonableness). Ironically, unlike criminal law, much of the corporate conduct that ultimately results im mass liarms and tort liability is implicitly encouraged and respected (mass production, technology development, organizational growtll, expanded inarkets, cost-benefit assessments, risk-taking, and capital accumulation), ratler than carried on under the shroud of criminal enterprise.

The private law system permits decisions about the imposition of risks, expenditures of funds, and social utility to be made by private corporations behind closed doors, and then, if liarms result and remedies for those liarms are pursued, those decisions niay be cliecked or evaluated later im open courtrooms by judges and juries. The manner in which we resolve inass tort conflicts betwecn corporate risk-imposers and members of the public and whetler we understand corporate imposition of risk as public or private reflect our basic norms and values. Public law is supposed to enforce our publicly decided standards, norms, and values. It would seem that public norms and values about imposing risk on others slould be subject to public debate and public decisionmaking, ratler than remaining a matter of private, individualized concern. Yet corporate impositions of risk on otliers are considered private decisions and governed by private law.

To add to the public/private confusion about corporate beliavior and mass torts, it is liard to categorize the large corporate defendants appropriately. Corporations are, in some sense, public wlien their sliares are publicly traded; yet they are private in their managenent, and distribution and ownership of assets and profits. Many large corporations own niore assets, possess more political and economic bargaining power, and often employ more people tlian many public, governmental bodies. Some multinational corporations are larger in terms of assets, employees,

46. Professor Owen notes that tort law may rectify private wrongs, but it is "often public in its spirit and effect." David Owen, Deterrence and Desert in Tort: A Comment, 73 CALIF. L. REv. 665, 667 (1985). 
and shareholders than many countries in the world. ${ }^{47}$ Perhaps there is something about the size, wealth, power, and numbers of people involved in large corporations that makes them more public than private, no matter how we have previously characterized them.

Our legal and political construction of the public/private split is incolierent, ${ }^{48}$ particularly when we attempt to apply it to mass torts. By labeling large, publicly traded corporations as "private" and applying private law, we insulate them from regular and thorough public scrutiny of their decisionmaking (except with regard to the ways they affect investors) and protect their liberty to act undemocratically in decisions that affect large groups of people (except with regard to shareholders). We also accord them "rights" such as free speech, 49 and unlimited property ownership and profit accumulation. They are treated as individual human beings, despite the reality of their increased collective power, knowledge, capacity for domg damage, and wealth. ${ }^{50}$ Historically, the label "private" effectively insulated choices and conduct from public scrutiny or censure. 51 Since those entities labeled "private" avoid gov-

47. See Phillip Blumberg, The Megacorporation in American Society: The Scope of Corporate Power 175 (1975); Robert Stauffer, NATION-BuIlding in a Global EcoNomy: The Role of THE Multinational Corporation 12-13 (1973).

48. Many eininent legal scholars carefully have expounded upon the flaws in our legal systein's public/private distinction. See, e.g., Kenneth Casebeer, Toward a Critical Jurisprudence-A First Step by Way of the Public/Private Distinction in Constitutional Law, 37 U. MIAM1 L. REV. 379, 422 (1983) ("[T]o nakedly assert that there continnes to be a sharp line separating public action and private action simply deinonstrates the total formality or einptiness of the concept of the State or Sovereign."); David Kairys, Introduction, in The Polmics of LAw: A Progressive Critique 4 (D. Kairys ed. 1982); Karl Klare, The Quest for Industrial Democracy and the Struggle Against Racism: Perspectives from Labor Law and Civil Rights, 61 OR. L. REv. 157, 161 (1982) (weakness of the fields of labor law and civil rights law due to the distinction between public and private); Elizabeth Mensch \& Alan Freeinan, Liberalism's Public/Private Split, TixkuN, Mar.-Apr. 1988, at 24; Nadine Taub \& Elizabeth Schneider, Perspectives on Women's Subordination and the Role of Law, in The PoLrmcs of LAW, supra, at 117. See generally Symposium: The Public/Private Distinction, 130 U. PA. L. REV. 1289 (1982).

49. See First Nat'l Bank y. Bellotti, 435 U.S. 765 (1978).

50. See John Flynn, The Jurisprudence of Corporate Personhood: The Misuse of a Legal Concept, in CORPORATIONS AND SOCIETY: POWER AND ResponsibILITY 131, 133 (W. Samuels \& A. Miller eds. 1987). See generally M. DAN-COHEN, supra note 35, at 26-30 (discussing the personification of the corporation and the corresponding rights it enjoys).

51. See Taub \& Sclineider, supra note 48 , at 117 . By shrouding the home in the private spliere, the government provided no recourse for spouse and child abuse. See Olsen, supra note 41, at 1501. Heterosexual men, as inakers of the law, could insulate their conduct in their home from governmental purview by labehing it private. The legal system's labeling corporate deeisionmaking as private allows corporations to insulate their workings from public view. On the other hand, since gay inen have not been empowered to inake laws that accommodate their own perspectives, their private consensual conduct is interpreted as sufficiently public to permit government interference. See Bowers v. Hardwick, 478 U.S. 186, 194-96 (1986). There also is a frightening possibility that women's decisions about whether to choose to reproduce will be deemed sufficiently public to permit governmental interference on a state-by-state basis. See Webster v. Reproductive Health Servs., 109 S. Ct. 
ernment control, it is not surprising that powerful corporations have acquired that label for thenselves. The public/private distinction is about politics and power, not a description of reality.

Decisions about imposing risks on the public and the social mechamisms for coping with the larms resulting from those risks are public questions of the highest order. Today, mass tort actions are semi-public and semi-private: They borrow from botli concepts, but are consistent with neither. The tort system fails to deal appropriately with mass tort, in part because it tries to fit itself within this antiquated, artificial dichotoiny between public and private law-a wholly maccurate representation of experience and material reality that undermines its effectiveness. We need to recognize that there is no chasm or clear distimction between public and private that ought to control available methods for understanding corporations and for resolving mass tort. ${ }^{52}$ We need to name a new category rather than adhere to abstract, reified notions of private and public. We need the freedom to rethink appropriate rules and remedies in light of the newer contexts and circumstances of the cases, without the prior constraints imposed by classifications of public versus private entity, or public versus private law, or public versus private liarm.

In addition to the fallacy of the public/private dichotomy, the law makes unrealistic distinctions between the individual and the collective, particularly with respect to understanding and imposing responsibility for corporate harms. Our private law system assumes individual players act as individuals, and individual rights conflicts are resolved by and for those individuals. Even when the law miposes responsibility on a corporation, it sanctions the corporation as if it were an imdividual or single unit whose assets are subject to damage awards or fines, rather than as a collectivity of people. Notions of collective responsibility only seem clear in terms of public entities or governmental bodies. For government actions, we acknowledge that a government agency or pohtical entity represents all of us and makes us all responsible to the extent that reparations for harms coine out of public coffers: In other contexts, discussions of

3040, 3058 (1989); Hodgson v. Minnesota, 853 F.2d 1452, 1466 (8th Cir. 1988), aff'd, 110 S. Ct. 2926 (1990); Akron Center for Reproductive Health v. Slaby, 854 F.2d 852, 868 (6th Cir. 1988), rev'd, 110 S. Ct. 2972 (1990); Turnock v. Ragsdale, 841 F.2d 1358 (7th Cir. 1988). Once something is labeled public, it is subject to regulation and government control. The labels private and public are not really descriptive but entail significant political consequences.

52. Although Professor Rosenberg is making a different kind of critique, he also recognizes the fallacy of the public law/private law distinction in mass tort. Rosenberg, supra note 41, at 925 . $\mathrm{He}$ concludes that the division between private and public law remedies impedes the just resolution of very complex cases and he proposes the use of certain traditional public law remedies to resolve mass tort cases. 
collective responsibility are said to violate some fundamental precepts of our law. 53

Although the law treats corporations differently from governments and governmental units, corporate collectivities do not fit neatly into the private, individualized analysis of harms or responsibility that courts apply. How should the law treat collectives, groups, organizations, or individuals that work together (or who work independently in the same market) to cause harm? The law should provide separate mechanisms and new rules to deal with individuals who work together to create harms and corporations organized for private profit.

We certainly can imagine circunistances in which an individual could be said to have acted alone in cansing a harm, although mass harms are almost inconceivable in terms of one individual or "person" acting alone. ${ }^{54}$ The magnitude of mass harms results from the combined actions and decisions of many people acting together to create products or perform activities. Not only do we permit people to act together in this manner, we encourage it and shield it from most public interference. We recognize how people working together in corporations create efficiencies that could not be achieved by people working alone. Now we also have to recognize how those combinations of people increase their capacity to do harm and interfere with our ability to determine who is responsible.

If the dichotomy between individual and collective ever made sense, which I doubt, ${ }^{55}$ it is unworkable in our modern era of corporate entities. Modern corporations are complex, multifaceted, integrated organizations of people who make far-reaching business decisions that create risks affecting inany people. Just as in the public/private dichotomy, the categories of individual and collective also have gotten away from us. Corporate activity and corporate responsibility are neither individual nor collective. We need to think of new ways to reconceptualize the experience of corporate activity-how corporate decisions are (and ought to be) made, and how we should assess the responsibility of people and groups within and across corporate entities for the harms that result.

53. See Abraham, Dilemma of Mass Tort, supra note 4; see generally INDIVIDUAL AND CoLLECTIVE RESPONSIBILITY (P. French ed. 1972) (using the massacre at My Lai to raise and investigate the moral and legal questions of individual and collective responsibility).

54. Ironically, a corporation often is treated in law as a "person" and for most purposes is represented as a single person. M. DAN-COHEN, supra note 35, at 27; PETER French, ColleCtIVE AND CORPORATE RESPONSIBILITY 31, 32 (1984); Flynn, supra note 50, at 138-42.

55. Radical feminist theory, for example, begins with a premise of human nature as interconnected and social in the first and final instance and whatever individualisin develops in the meantime is constructed and secondary. See AIISON JAGgar, Feminist Polmitics ANd Human NATURe 83118 (1983); Robin West, Jurisprudence and Gender, 55 U. CHI. L. REV. 1, 14 (1988). 
Corporate hability should relate to the harms caused. Personal responsibility ought to be based on power to make decisions about resources, markets, personnel, and safety, as well as power to disclose. Personal responsibility has to correlate with the power of individuals within corporate roles. ${ }^{56}$ While the law must protect imdividuals within corporations from becoming scapegoats for unlawful corporate actions, our legal system must try to assign personal responsibility in differing degrees to all those people who could have intervened and prevented harms from occurring. ${ }^{57}$ Concomitant with the personal responsibility, our legal system ought to provide some security to persons who act on that responsibility. ${ }^{58}$ The laws can be transformed to empower corporate employees and reduce risk of job loss for preventing corporate harms.

In addition to the confusion created between collective and individual responsibility for corporate-caused harms, we have difficulty applying the diclotomy of individual/collective to those harmed. We need to develop legal remedies that respond to the harms suffered by the groups of individuals as well as by the individuals within the groups. ${ }^{59}$ In some

56. The Supreme Court has approved the imposition of strict criminal responsibility on a Chief Executive Officer of a national retail food chain with 890 facilities and over 30,000 employees for adulterated food in one of its warehouses under the Federal Food, Drug, and Cosmetic Act, 21 U.S.C. $\S \S 331-93$ (1988), in United States v. Park, 421 U.S. 658, 672-73 (1975). Criminal liability in these cases attaches to responsible corporate agents who had the power to prevent or correct the prohibited conditions.

57. In theory, each individnal within the corporation could stop or report a corporation from causing larm about which he or she knows, but the corporation is the ouly entity to which "full knowledge" can usually be attributed. In reality, only people in certain roles have the knowledge or power to stop the corporation from acting.

58. Even if individual employees have access to adequate information, whistle-blowing statutes notwithstanding, the decision about whether to report corporate misconduct is a difficult one for employees who sec themselves as powerless to change corporate conduct and who, by reporting possible wrongdoing, risk loss of their jobs. See Foley v. Interactive Data Corp., $47 \mathrm{Cal}$. 3d 654, 765 P.2d 373, 254 Cal. Rptr. 211 (1988) (employee fired for reporting to management that his newly appointed boss was being imdicted for crimes against his former company); Shects v. Teddy's Frosted Foods, 179 Conn. 471, 472-73, 427 A.2d 385, 386 (1980) (employee dismissed after reporting to his employer several state violations including mislabeling of food weight and use of substandard raw materials); Elam v. Alcolac, Inc., 765 S.W.2d 42, $52-68$ (Mo. Ct. App. 1988) (attenpts by various engineers to report problems with plant were suppressed or disregarded and critics were fired), cert. denied, 110 S. Ct. 69 (1989); Pierce v. Ortho Pharmaceutical Corp., 84 N.J. 58, 62-64, 417 A.2d 505, 507-08 (1980) (scientist employee resigned under pressure for refusing to work on products produced by employer that she considered unsafe); Murphy v. American Home Prods., 58 N.Y.2d 293, 297. 98, 448 N.E.2d 86, 87, 461 N.Y.S.2d 232, 233 (1983) (employee fired after reporting to his superiors the illegal mamipulation of company pension plan by high-ranking officers).

59. A harm to a family inember is clearly a harm to the family as a group. To call it a larm to an individnal is to remove it from its context and reality, yet to call it a harm to a collective or group also misses the point. It is one harm that has many facets, affecting the needs of individuals, groups, and individuals as inembers of groups. This insight is not only true of families. People are mutually dependent. If a worker or workers are injured and can no longer work, there is a harm to other people at the workplace in a real, hived way. And what about harm to one's dear and close friends? 
ways, the law has tried to accommodate this phenomenon by procedural devices such as class actions and multi-district hitigation consolidation, but these devices do not alter the substantive understandings and categories of thought about victims and tortfeasors as individuals or collectives.

It is probably best with respect to corporate harms to drop the notions of individual and collective entirely. I do not mean that we should ignore the concerns of each person, or that we should fail to understand that groups act as single wholes but with greater force. I do mean that the law must begin from premises that human beings are imterconnected in their hives. The legal system must reconceptualize corporations as social entities consisting of collections of people all working together or interacting with others inside and outside the corporate group.

Large, publicly traded corporations ought to be a category sui generis in law. We need separate laws to deal with their organization, function, and responsibilities. The fact that these mass harms are created by corporations in the pursuit of private interest, not public benefit, is particularly important in formulating these laws. Their activities should not be privileged, but rather should be subject to careful scrutiny and sensitive appreciation of the interactive nature of people working in

Are the intimacies of close personal relationships and their mutual dependencies invisible to the law? Our legal system inust recognize our mutual dependence. We can hardly imagine an individual without some intersecting social groups, so that the concept of individual as isolated and capable of being harmed alone is almost inconceivable. The failings of this reasoning have led courts, lawyers, and plaintiffs to try to fabricate unique rules and peculiar new causes of action to respond to these real, lived experiences of harm caused to interrelated meunbers of social and familial groups. These new causes of action include the following: 1) loss of consortium, see, e.g., Rodriguez v. Bethleliem Steel Corp., 12 Cal. 3d 382, 525 P.2d 669, 115 Cal. Rptr. 765 (1974) (spouses may recover for loss of the eaclı other's services and consortium); 2) loss of parental society, see, e.g., Ferriter v. Daniel O'Connell's Sons, Inc., 381 Mass. 507, 413 N.E.2d 690 (1980) (children may sue for loss of parental consortiuun); Berger v. Weber, 411 Micl. 1, 303 N.W.2d 424 (1981) (child has independent cause of action for loss of parental society); Hay v. Medieal Center Hosp., 145 Vt. 533, 496 A.2d 939 (1985) (minor child has right to sue for damages for the loss of parental consortium); 3) loss of comfort and society of children, see, e.g., Ahrenholz v. Hennepin Connty, 295 N.W.2d 645 (Minn. 1980) (parents may be compensated for loss of advice, comfort, assistance and protection which they reasonably could have expected had the child lived); Shockley v. Prier, 66 Wis. 2d 394, 225 N.W.2d 495 (1975) (parents may recover damages for loss of aid and society of minor child); 4) negligent infliction of emotional distress actions brought by "bystanders," see, e.g., Dillon v. Legg, 68 Cal. 2d 728, 441 P.2d 912, 69 Cal. Rptr. 72 (1968) (close relative may recover for emotional distress resulting from viewing serious negligent imjury to child); 5) wrongful birth, see, e.g., Berman v. Allan, 80 N.J. 421, 404 A.2d 8 (1979) (parents may recover for emotional distress caused by birth of child with genetic defects); 6 and others, see, e.g., Molien v. Kaiser Found. Hosps., 27 Cal. 3d 916, 616 P.2d 813, 167 Cal. Rptr. 831 (1980) (husband can recover for emotional distress suffered as a consequence of wife's syphilis misdiaguosis).

Although these atteinpts to shape the law to reflect the experiences of victims and families have been presented as examples of our overly litigious society, it might be more accurate to understand them as symptomatic of a cry for the legal systein to recognize that we are mutually dependent beings who suffer along with those victims whose lives are interwoven with our immediate social units. 
groups. Their special nature also might require that their decisionmaking processes and information be exposed to public observation, or even that certain kinds of corporate decisions require democratic participation by people inost directly affected. For the legal systein to deal appropriately with corporations, mass harms, and the liability crisis, we inust abandon the false dichotomies of public/private and individual/collective. We must create feminist (re)torts.

\section{B. The Monetization and Commodification of Justice, Responsibilities, and Injuries}

The tort reform and tort law eradication movements rely in large part on a myth that common law tort rules, particularly in mass tort cases, regularly result in excessive and arbitrary jury verdicts. ${ }^{60}$ Although there are isolated examples of exceptionally large inonetary judgments in individual cases and also of inconsistent verdicts, ${ }^{61}$ a fair argument has been inade that those rare judgnents are over-publicized and inanipulated by the defense bar and insurance companies, in order to lobby the public and legislatures for tort law reform. ${ }^{62}$ There is no comparable group that lobbies about, or pubhicizes, all the low or mid-sized settlements and verdicts in mass tort lawsuits, or the potential cases that were never brought. ${ }^{63}$ Nevertheless, accepting the premise that there are unfitting verdicts (for purposes of arguinent only), this phenomenon probably rests on three underlying inyths.

The first myth is that injured plaintiffs are inoney-hungry, and great sums of nioney motivate then to sue-which they do too often, too easily, and for too nuch. Concomitantly, there is a parallel niyth that juries in personal injury actions are swayed by inappropriate sympathies for injured plaintiffs, resulting in irrational judgments unwarranted by principles of justice and fairness. Both these niyths attribute to conimon law tort the fatal flaw of being a catalyst for greed. The third myth is that nioney damages are all our legal systenı effectively can offer for tort plaintiffs.

Because our political systenı does not provide assurances that each of our injured citizens will have the appropriate liealth care and money

60. See Sugarman, Tort Law, supra note 23, at 592-96.

61. See Abel, Too Few Claims, supra note 18, at 443-45; Sugarman, Taking Advantage, supra note 11 , at 336-37 \& nn. 44-46.

62. See Abel, Too Few Claims, supra note 18, at 445.

63. This comment is not intended to underestimate the work of Ralph Nader and his colleagues. See Andrew Blum, Back in Vogue?: "Raiders" at 20 Look Forward, Nat'l L.J., Jan. 8, 1990, at 24, col. 1 (discussing Nader's activism as it relates to the legal system); Ralph Nader, The Corporate Drive to Restrict Their Victims' Rights, 22 GoNZ. L. REv. 15 (1986-87) (praising the present tort system but encouraging state and federal governments to increase policing activity). 
for necessary living expenses, tort victims are forced to translate part of their claims for justice into claims for money to pay for these needs. Furthermore, they may be forced into the tort system when they would prefer not to litigate at all. Even if tort victims have first-party insurance or healtll care benefits from other sources, there still may not be compensation for lost wages, lost earning capacity, or other special econoimc losses. These unmet needs are a function of distributional injustices in our pohtical system: If everyone had access to needed health care and incoine inaintenance during disability, then tort litigation seeking monetary compensation for these expenses would be unnecessary and superfiuous. ${ }^{64}$ If our pohity avoids addressing tliese systemic, political problems of healtl care and income maintenance, they will continue to plague any justice system we have and will fuel hability crises like the one we presently are experiencing.

In addition to an absence of needed health care and a substituted income for lost wages while recuperating, we also fail mjured citizens in equally important non-inonetary ways. Non-inonetary needs of disabled people include the following needs: affirmation of worth and dignity; public recognition of the injustices they suffer; desires for sincere, personally conferred apologies; added demands for caretaking services; public forums to air their grievances; and affirmation that justice and equality matter in our society. Our legal system cannot continue to ignore the pain and sacrifices that our political and econormic systems have exacted from our injured nneinbers.

As a society we have not taken satisfactory steps to guarantee that people with disabilities will be respected and cared for in their non-1nonetary needs. Physical, mental, and psyclıological disabilities often prevent citizens from inanaging or being responsible for ordinary tasks to take care of theinselves and their families. Money can ease the burden, but it does not assume tliose particular responsibilities. ${ }^{65}$ Nor do we liave a system that overtly recognizes that individual victims are neinbers of social groups and families, and therefore remedies or assistance inust take into account the newly constituted needs and circumstances of tort victims' families and intimate relationships. ${ }^{66}$

64. Several other tort scholars have argued for the need for socialized systems of medical care and income maintenance. See, e.g., Sugarman, Taking Advantage, supra note 11, at 358-59; Abel, Torts, in THE POLITICS OF LAW, supra note 48, at 185.

65. Although some caretaking services can be purchased if there are adequate financial resources available, inany responsibilities have to be provided by families and friends.

66. When I nse the term "family" throughout this Article, I mean people who take primary responsibility for caring for one another. I do not mean the word to be defined by blood relations or legally defined states, such as marriage, although those conditions can be predecessors to a family relationship. Families can be lovers, friends, or communal hiving situations. 
Tort damage awards have made a feeble attempt to recognize some of these needs of tort victims. Some damage awards reach elevated sums based on intangible injuries (noneconomic loss for pam and suffering, loss of enjoyment of life, loss of consortium, increased risk or loss of chance, cancerphobia, emotional distress, and the like). These dollar amounts often are added to already massive compensatory awards for past and future hospital and medical expenses, past and future wage loss, rehabilitative expenses, and other special economic loss damages. For many advocates of damage caps, the costs of economic loss damages are perhaps justifiable, ${ }^{67}$ but inonetary damages for non-economic loss are mappropriate and distort the econony and judicial process. ${ }^{68}$

Money cannot begin to compensate for the loss of a loved one, nor for the paim and suffering one must endure with a debilitating, deforming or degenerative injury. The fear of contracting deadly diseases from unconsented exposure to toxic substances, the inability to have children or the pain of having children who are genetically injured, and the indiginty and dehumanization of being a calculated risk of loss in a corporate profit quest are non-compensable. ${ }^{69}$ Tort judgments are money judgments because we have not developed any other "coim" of worth or value in our society. This limited ineasure of value is a sad statement about all of us, not about the tort system. Since injured victims are already in court seeking inonetary compensation for their out-of-pocket expenses, it is not surprising that they would seek monetary compensation for all their injuries, including their emotional distress, their increased risks, damages to their family relations, and the like. If those facets of injury go "uncompensated" by tort or are "unacknowledged" by tort remedies, the severity of these harms would be demeaned.

Until we devise other legal remedies that respect all the realities of these injuries and seek to alleviate these harms, how can we blaine coin-

67. Advocates of damages caps on non-economic losses also usually propose abolition of the collateral source rule. By eliminating the collateral source rule, defendants will not be responsible to pay plaintiffs (actually plaintiffs' insurers) for health care coverage or other first-party insurance that paid plaintiffs' imitial out-of-pocket expenses.

68. See AtTorney General COMM. Report of the TORT Policy WORKINg Group ON the Causes, Extent and Policy Implications of the Current Crisis in Insurance AVAILABILITY AND AFFORDABILITY, in Liability Insurance Crisis, Hearings Before the Subcommittee on Economic Stabilization of the House Committee on Banking, Finance and Urban Affairs, 99th Cong., 2d Sess. 197-279 (1986) (calling for a statutory limit on non-econounic daunages); Note, 1986 Tort Reform Legislation: A Systematic Evaluation of Caps on Damages and Limitations on Joint and Several Liability, 73 CORNELL L. REv. 628, 635-38 (1988).

69. Richard Abel, who argues that the problem of tort law is underclaiming, criticizes tort law for commodifying love, pain and suffering, loss, and other intangible harms by translating them into inonetary awards. Abel, Too Few Claims, supra note 18, at 443-44. Accord Ingber, supra notc 31, at 783-85 (monetary awards for non-pecuniary damages do not provide ineaningful compensation to the vietim of an intangible injury). 
mon law tort or tort victims for following our social norms and translatmg imtangible mjuries into the materialist language of our culture, the language of dollars? Our society ineasures the value of everything in terms of dollars-labor, property, rights, harms, breaches of promises, even injured relationships. Some beinoan valuing life, injuries, or pain in dollars, but because we constantly fail to devise another medium, we fall back into the language of money. If we implore courts not to deinean the harm by awarding money, then we provide "no compensation" at all. By taking an all-or-nothing approach, the legal system, and consequently the tort system, has forced plaintiffs into prayers for money dainages to coinpensate these intangible injuries. Denying legal recognition of the harm by failing to award money or devise alternative "compensation" sends negative messages to plaintiffs about the importance or value of their lives, autonomy, and the range of their suffering. When our justice system fails in this fashion, it risks losing the consent of the governed.

Monetary tort damages veer far from the mark in compensating for intangible injuries, but the legal system has been silent about alternatives. Critics have blamed common law tort wrongly for this problem. We should look closer to our core. If we criticize the commodification of injury-a wholly justified criticism-our focus should not be on tort law and tort reform but rather systemic pohtical, economic, and social change. When we have changed our values, ethics, and ideology, tort law will follow. It is not the responsibility of tort law to change our value system, norms, and perspectives. Tort rules can cooperate im those changes, or nudge them along, but they cannot act alone. The monetization of mjury is a structural defect in our legal system. We must decide collectively that health, safety, and human relationships take priority over economic efficiency, freedoin of contract, and private profit. Our legal system must be more imaginative and responsive to the real huinan needs and circumstances of tort victims. This is one of the most appropriate places in law for compassion, empathy, and caring. ${ }^{70}$

Not only do we translate imjuries and pam into dollars, we also translate responsibility into dollars. ${ }^{71}$ If our justice system attributes re-

70. See Lynne Henderson, Legality and Empathy, 85 MrcH. L. REv. 1574, 1575 (1987) (empathy aids the procedures by which a judge or other legal decisionmaker reaches a conclusion and the processes of justification in a way that disembodied reason cannot).

71. Dollars and their equivalents have become our society's foremost value. We may have an ideology about other values, but when push comes to shove, dollars win. In this manner, the risk of injury and its costs can become an exchangeable commodity. From this insight, some torts scholars are now arguing that one should be able to bargain for grcater or lesser risks to life and limb at different costs. P. HubER, LIABILITY, supra note 17, at 18; Robert Cooter \& Stephen Sugarman, $A$ Regulated Market in Unmatured Tort Claims: Tort Reform by Contract, in NEW DIRECTIONS IN LIABILITY LAW, supra note 18, at 174. 
sponsibility to parties for harms and has at its disposal only the possibility of making monetary awards against those parties, then responsibility ultimately becomes solely a monetary obligation. It may even end up as a monetary obligation drawn from another's resources rather than from the person who generated the harm, because payment is made by prepurchased hability imsurance.

Justice is purchasable. ${ }^{72}$ The quality of representation and the likehhood of getting a lawyer to represent you often depends upon low much you can pay or how much the lawyer can expect to recover. This is most clearly evident when we compare the civil justice system to the criminal justice system. In criminal court, where defendants' hives and liberties are threatened, representation often is provided by publicly-funded lawyers who are overworked and underpaid, and whose resources are neghgible. Yet, when the issue in a civil lawsuit is low dollars should be passed around anong corporations and individuals (e.g., mergers, leveraged buy-outs, securities, antitrust, mass tort, government contracts, copyright and patent infringements, major personal imjury, real estate transactions), there is top-notch representation on every minor procedural point. Money speaks loudly im our justice system. Monetary disputes seem to take priority over issues of life and liberty in terms of the legal resources devoted to them. And money certainly affects the availability of lawyers and resources.

Ironically, we generally maintain the behef that the ideal of justice is above the fray of commodification that otherwise las corrupted the tort system. The unexplained gap between the ideology of the justice system and the realities of its functioning creates a cognitive dissonance that lias been attributed wrongly to cominon law tort and has motivated sonie of the strongest tort reforn claims. The legal system in general-not just the tort system-has commodified justice, and we shonld not be surprised when tort juries and tort victims understand this insight and react by moreasmg awards to reflect their sense of the injustices suffered by plaintiffs.

Justice requires a sensitivity to the experiences of the parties, the contexts of their conflict, and the preservation of their relationships. Jus-

72. Since one goes to court to seek justice, and since going to court costs a great deal of money, justice, as well, has been commodified and monetized. This is particularly evident in the trend to settle inost tort cases. Professor Marc Galanter reported in 1986 that inany cases are settled or terminated after filing but before trial. Marc Galanter, The Day After the Litigation Explosion, 46 MD. L. REV. 3, 8 (1986) ("In the federal courts, cases reaching trial have fallen from $15.2 \%$ of terminations in 1940 to $5.0 \%$ of terminations in 1985. In state courts, too, a smaller portion of cases is decided by full contest than in the past." (footnotes omitted)). Since justice is a commodity that can be purchased, if the inarket value of justice (e.g., the cost of a jury trial) is too high, then it can be purchased in lesser amounts or other forms, as with other commodities. 
tice involves care, dignity, and respect. It is the glue that holds together our trust in the legal system, our support for its legitimacy. When a tort plaintiff finally works up the anger or courage to entangle herself in this alienating systein, she does so because she feels an absence of justice. She feels that unless something is done to acknowledge (and right) the wrong she suffered, she can no longer trust the system. ${ }^{73}$

For our social order to be successful, we all need to believe that there is a place where we can find just resolutions of our conflicts, reinedies for our harms, appreciation and acceptance of our differences, and recognition for our individual and common humanity. The tort system has the potential to provide the appropriate reinedies for some plaintiffs, some of the time. The substitution of a statutory monetary compensation prograin, socialized health care, claims facilities, or alternative dispute mechanisms will not meet these needs. Those substitutions may all be important steps for planitiffs, but unless all other kinds of hitigation are eliminated or altered im a similar fashion, mass tort plaintiffs will be less empowered rather than more.

Justice is a passionate concept that inspires us. Behef im its presence motivates us to go on with life; its absence angers and frustrates us and causes hatred. Money provides no substitute. An order for the payment of money might indicate the state is trying to ensure that justice is done, but the payment of money does not aniount to justice. Monetary compensation is only a part of the motivation of imjured parties im tort actions. If coinpensation for out-of-pocket expenses were provided through some insurance or statutory compensation scheine, all plaintiffs' needs still would not be met. I suspect plaintiffs would continue to use a judicial system. There is a human-social need for dignity, respect, empowerment, and an ideology of fairness that a system of justice provides. This aspect of the judicial system cannot be replaced or eliminated without serious consequences to our communal well-being. If we permit imjured parties to seek justice through lawsuits when their commercial contracts are broken or their property is impaired, but only permit resort to a statutory coinpensation progran for injured parties when their bodies are mainned or their health impaired, we send a strong inessage about what

73. In order for our society to function, we must consent to our social and political organizations. We need trust, belief in possibilities of fairness, justice, equality, respect, and social community. Even if these are only shared myths, we need to believe in them, otherwise we will opt out or fight for them to be restored. We can opt out by being criminals, anti-social, alienated, angry émigrés, or revolutionaries, or we can stay and either fight back through political processes, litigation, and protests, or through extra-political process like riot and revolution. In his Chronicle of the Celestial Curia, Professor Derrick Bell explains soine of these options for people disillusioned in our social-political-legal order. DERRICK BELL, AND WE ARE NOT SAVED: THE Elusive QUEST FoR RACIAL JUSTICE 51-74 (1987). 
we value in society. What can we expect injured plaintiffs to feel about the meaning of justice in our society when courthouses are available to remedy economic and property transactions but not to remedy wrongs to health and well-being? If alternative dispute mechanisms are required for mass personal injury actions but not for other harms, that saine message is sent. Why are these physically, emotionally, and psychologically imjured people being stecred from courthouses, while people disputing about property and money find unobstructed passage?74

If we blane the tort system for translating imjury and harms into money, we are making the same kind of mistake we make when we blaine a rape or doinestic violence victim for male violence agamst her. As I explained earher, we inust seek out the appropriate source of responsibility for this state of affairs. This Section of my Article has illustrated a few of the problems of our legal political system that have fueled the hability crisis. These general problems of our legal system have been wrongly blamed on common law mass tort. I suggest that the blaine cast upon mass tort law has diverted our scholarly, practical, and pohtical attentions from the root of the problem. The current hability crisis will not vamish unless we make changes in the way in which our legal system understands corporations and the mass harms they cause, rids itself of false dichotomies, finds alternatives to hitigation for economic loss, and creates new remedies for imtangible injuries suffered by mass tort victims. In the next two Sections, I propose specific modifieations of mass tort law and remedies.

\section{The Burden of Proof and the Presumption of NONLIABILITY IN MASS TORT CASES}

I still beheve, despite much contrary evidence, that the end or goal of a judicial process in the United States is, or at least ought to be, justice. Recognizing that justice is not a "thing" with clear boundaries and content, and that what is just is often open to dispute and disagreement, there are still some prerequisites for just resolutions of disputes on which we generally agree. One necessary prerequisite to justice is the equalization of power between disputing or conflicting parties. If one party can overpower another, then problems are solved by brute strength, wealth, or privilege. Justice, im contrast, requires consideration of the particular facts and circumstances underlying the dispute. In this Section, I argue that in mass tort actions the estabhished judicial process fails to balance the power of imjured plaimtiffs and corporate defendants, and that such a

74. See Daan Braveman, Protecting Constitutional Freedoms: A Role for FedERAI COURTS 125-30 (1989). 
balance is a necessary prerequisite to a truly just resolution. To begin to balance the power between injured plaintiffs and corporate defendants, I explore the idea of shifting the burden of proof and the presumption of nonliability in inass tort cases.

In our current formulation of inass tort law, we presume the plaintiff will be "strictly hable" for her own harm ${ }^{75}$ unless she can prove that the defendant was "at fault," the activity was abnormally dangerous, ${ }^{76}$ or the product was "defective."77 In a tort system primarily based on fault, this presumption, in effect, results in the imposition of hability upon a "faultless" party. ${ }^{78}$ There is nothing natural or necessary about the presumption that the injured party should bear her own loss unless she can shift it through legal procedures. ${ }^{79}$ The dubious placement of the initial econormic loss and the burden of proof can be attributed to two imissteps in reasoning. First, the false parallels that are made between who bears the burden in criminal and civil cases, and second, the justice system's failure to consider power imbalances and inequalities in determining who should bear burdens of proof and production.

\section{A. Rationale for Allocation of Burden of Proof in Criminal Law}

In our criminal law system, the state, with all its power, seeks out and prosecutes alleged wrongdoers. Controversies between citizens are translated through the criminal law into controversies about the wellbeing and maintenance of the commumity. The state uses its consensual, collective, coercive power to rectify wrongs to the public. The inight of the state's legal apparatus is aimed at the accused. For this reason and because of the potential for abuse of power and inequality when the public power charges a private entity or individual, we have a system that initially favors a defendant with presumptions of innocence and the power to force the state to bear the burden of proof without the defendant's assistance. A criminal defendant is presumed innocent until proven guilty; she is permitted to sit silently and let the state make its proof or fail to convict lier. As if there were actual balance scales weighing the

75. This common law presumption was plainly articulated by Justice Holmes in the 19th century and carries forth to this day. OlIVER Wendell Holmes, The COMMON LAw 76-78 (Howe ed. 1963) ("The general principle of our law is that loss from accident must be where it falls.").

76. RESTATEMENT (SECOND) OF TORTS $\$ \S 519-20$ (1976).

77. Id. $\S 402 \mathrm{~A}$.

78. See Jules Coleinan, The Morality of Strict Tort Liability, 18 WM. \& MARY L. Rev. 259, 260 (1976).

79. Guido Calabresi and his co-authors have suggested a reverse Learned Hand test where the loss would lie with the injurer unless the victim could have avoided the accident inore cheaply. Guido Calabresi \& Alvin Klevorick, Four Tests for Liability in Torts, 14 J. LEGAL STUD. 585, $587-$ 91 (1985); Guido Calabresi \& Jon Hirschoff, Toward a Test for Strict Liability in Torts, 81 YALE L.J. 1055, 1077 (1972). 
power of a defendant and the state, the state's initial advantage rooted in its presumptively greater collective power and resources is countered or "balanced" by the weightier burdens of proof (persuasion and production) and presumption of innocence, so that ultimately the balance is level. If the burden of proof and the presumption of irmocence were not available to criminal defendants, the state's collective power would unjustly overpower a defendant. Many judicial systems do not afford a criminal suspect this benefit; they do not inake an attempt (even an ideological attempt) to equalize the power of the parties, or to level the power of the most powerful party (i.e., the state). ${ }^{80}$ The power-leveling accomplished by the allocation of burdens of proof on the state (plus the "beyond a reasonable doubt" standard of persuasion) and the presumption of innocence for the defendant in our criminal system promotes our belief that justice is being done rather than raw power being exercised. ${ }^{81}$ It is inappropriate in mass tort cases against large, public corporate enterprises to require injured plamtiffs to bear a similar burden of production, persuasion, and proof to that borne by the state in criminal cases. Reducing the standard of persuasion required in mass tort from the criminal "beyond a reasonable doubt" standard to a "preponderance of the evidence" standard 82 does not eliminate the problem.

In our cominon law system of civil or private law justice, the state is not a party to controversies between citizens. It does however, provide a forum for the resolution of conflicts, provide the rules of law and procedure, promote an ideology about the availability of justice in that forum under those rules, decide the conflicts, and offer its power for the enforce-

80. Witness, for example, the recent prosecutions and executions of the Chinese workers involved in the Tiananmen Square protests in June 1989. See Nicholas Kristof, Troops Attack and Crush Beijing Protest; Thousands Fight Back, Scores Are Killed; General Strike Is Urged as Officials Announce End of 'Rebellion,' N.Y. Times, June 4, 1989, § 1, at 1, col. 6; Paul Lewis, China Is Said to Execute Some in Secret, N.Y. Times, Aug. 31, 1989, at A3, col. 4. These Chinese workers were not even permitted to put on a defense.

81. Good arguments can be made that these beliefs are a false ideology that does not match the material reality, and that it is actually disempowering and pacifying to maintain this ideology bccause people consent to something that is not "real." See Gabel \& Harris, supra note 45, at 374; antonio Gramsci, Selections from the Prison Notebooks of ANTonio Gramsci (G. Nowell-Smith ed. 1971). Although I am persuaded by this argument, I remain undecided about what strategy to take, and I feel that it is useful to argue within the ideology as well as against the ideology's disempowering aspects.

82. Steve Gold distinguishes between the burden of proof (of causation) and the standard of proof (preponderance of the evidence), and criticizes the law for collapsing these two separate concerns. Steve Gold, Causation in Toxic Torts: Burdens of Proof, Standards of Persuasion, and Statistical Evidence, 96 YALE L. J. 376, 378 (1986). For purposes of this essay, I use "burden of proof" to mean an obligation to produce evidence and convince a court or jury about the correctness of a position in order to prevail. Wigmore referred to this as the "risk of nonpersuasion" and "the risk of nonproduction." 9 JOHN WIGMORE, EVIDENCE IN TRIALS AT COMMON LAW $\$ \S 2485,2487$ (J. Chadbourn rev. ed. 1981). 
ment of its decisions. As the provider of forums for justice and as the judge, the state fails mass tort plaintiffs.

In many ways, mass tort actions are more like public law actions than the private law actions that traditionally have been used to resolve other kinds of accident disputes. ${ }^{83}$ Mass torts usually involve many plaintiffs, public harms that can be wide-spread or slow-developing, needs for deterrence of further similar conduct, and enormous potential burdens on the judicial system. Unlike the parties to an ordinary accident case, mass tort plaintiffs typically are less empowered than mass tort corporate defendants. ${ }^{84}$

\section{B. Disparate Empowerment of Injured Mass Tort Plaintiffs and Corporate Defendants}

As with criminal cases, mass tort cases involve disputes between citizens about public harms that need to be rectified. But in the mass tort/ corporate liability context, we have private citizens (rather than the state) utilizing their own resources to right these wrongs and remedy the harms. In many ways, this opportunity for private initiative is a glory of tort law, because an injured plaintiff is not dependent upon the will and energy of the state to prosecute her claim. The tort systein permits ordinary citizens to call any defendant to answer for his alleged wrongdoing. Neither the specific consent nor participation of the state is required. To a small extent, a plaintiff is imbued with the power of the state-a power to require or coerce a defendant to come forward and answer or risk a loss. But a plaintiff does not have the state power behind her in any other way. She does not have the economic or pohtical resources of the state, legal representation by state attorneys, access to information, collective power, authority or legitimacy, or the background power to einploy force if necessary. ${ }^{85}$ While groups of plaintiffs may accumulate some power by virtue of their numbers, their power is neghible compared to organized corporate entities. Plaintiffs' groups are tenuously connected because one group's success inay conflict with the success of another group, due to limited corporate assets available for coinpensa-

83. For a discussion of the public/private law distinction, see supra note 41 .

84. In accident cases, in which defendants are associated with others who have power over the defendant (einployment contexts, car ownership liability), the law often imposes vicarious liability on the einpowered party.

85. Plaintiffs may gain some colleetive power by combining with other plaintiffs in class actions, or by consolidating their claims for certain purposes. See FED. R. CrV. P. 23. This collective power, while valuable, differs from the collective power of the state (or even a corporate defendant) because it is created spontaneously for purposes of the hitigation and is not pre-existing and preorganized. See supra text accoinpanying note 80 . 
tion. In addition, their joint success inay be dependent upon newly formed associations with strangers who also happen to be victims. ${ }^{86}$

Despite differences between the state and private plaintiffs as imitiators of actions, corporate defendants in mass tort suits still coine to court with much of the saine protective coating defendants are afforded in criminal actions brought by the state. They are clothed in a presumption of nonliability (akin to the presumption of innocence), and the burden of proof is on the injured victim-plaintiff (as it is on the state). The corporate defendant is advantaged by the judicial allocation of the burden of proof and presumption of nonliability. The law pays no attention to whether a defendant is an individual or a highly organized corporation of inordinate wealth and power. ${ }^{87}$ Defendants are given free rein to utilize their wealth, knowledge, and familiarity with the legal system, even if they greatly exceed that of the plaintiff. Defendants can delay, obstruct, and out-price plaintiffs. Defendants need not make their proof at all, if a plaintiff cannot first prove her prima facie case. In blatant disregard of the unequal power, the presumptions about the appropriate initial bearer of the economic loss and the burdens of proof he in a defendant's favor.

In all tort cases, but particularly in mass torts, the injured parties have multiple burdens to bear. Not only are they burdened by the pain, mjustice, and disruptions caused by their mjuries, but they also are tangled in a legal systein which is unfamiliar, alienating and ritualized. ${ }^{88}$ The plaintiffs must take on the burden of rectifying the harm they suffered by identifying the harm-causers, discovering the nature and extent of the risks imposed and harms resulting, and taking corporate defendants to court to force thein to take responsibility for the consequences of

86. Some plaintiffs in mass tort cases have tried to compensate for their lack of power and resources by relying on entrepreneurial, risk-taking activities of law firms who provide front money for these hitigations-and even on investor attorneys who purchase interests in mass hitigation. This strategy raises many ethical questions between lawyers and clients that need to be explored further, particularly in regard to settlements. See, e.g., In re A.H. Robins Co., 88 Bankr. 742, 747 (E.D. Va. 1988) (Dalkon Shield bankruptcy); Lord, supra note 29 (Agent Orange settlement).

87. Defendants in mass tort cases are typically powerful corporations with economic, political, and opportunity power. See generally R. MokHIBER, supra note 33. In major mass tort bitigation, the defendants have imcluded corporations such as Johns-Manville Corporation, see id. at 277-88 (asbestos), Eli Lilly and Abbott Laboratories, see id. at 175-79 (DES), A.H. Robins Co., see id. at 157-61 (Dalkon Shield), Dow Chemical, see id. at 80-83 (Agent Orange), Hooker Chemical, see id. at 269-76 (Love Canal), Union Carbide, see id. at 93-94 (Bliopal), and Exxon, see Laura Mansnerus, A Paper Spill Due on the Valdez Case, N.Y. Times, Feb. 5, 1990, at D2, col. 1 (Valdez oil spill). Unlike a fortuitously associated group of plaintiffs, defendant corporations are pre-organized and unified within their corporate structures, lave a single purpose with respect to the litigation, usually have im-house or retained counsel (and hence immediate access to legal information), access to imlouse experts and external funds for additional help, sources of information witlin the corporate structure, and many other pre-trial advantages.

88. See Gabel \& Harris, supra note 45; see also Duncan KENNEDY, LEGAL Education AND THE REPRODUCTION OP HIERARCHY (1983). 
their actions. Since a plaintiff is required to bear the loss unless she can shift it to another, I call this presumption the "presumption of liability" or "presumption of responsibility." The presumption theoretically could be placed on any of the parties to a dispute. In mass tort cases there is a presumption of nonliability for the corporate defendant-that is, a defendant is not liable for the harms or initial out-of-pocket expenses, unless a plaintiff can prove its liability. Until they settle or win their case, the costs of the aceident or injury loss falls on the plaintiff. These would not be insignificant burdens, even if iniposed on liealthy citizens, but in mass tort cases they rest even more lieavily on physically or emotionally harmed victims. Yet there is another dynamic besides placing the burden on an already injured party that significantly disables plaintiffs in mass tort.

The crux of my argument is that parties in mass tort litigation come to the courthouse differently einpowered. ${ }^{89}$ Because our ideology of jus-

89. For the moment in discussing differential empowerment, I am ignoring the cultural identity factors that disempower people in our society based on race, gender, class background, sexual preference, rehigious or ethnic background, age, or different physical capabilities. These are critical aspects of empowerment, and they are deserving of our constant and full attention. Nonetheless, for purposes of this Article, I am writing primarily about differences of wcalth, knowledge, access, and political power. These differences between mass tort victims and corporate defendants in mass tort cases parallel (and often even accompany) differential empowerment in society based on cultural identity. Despite an ideological pretense that parties involved in titigation are equals as they enter the courtroom, economic-social-political power is distributed unequally between parties, particularly in mass torts.

The unprivileged litigant, and particularly the tort plaintiff, is disempowered within the legal system by the use of formal rules and language that often are counterintuitive, unfamiliar, alienating, and arcane. These rules present artificial legal impediments that limit a tort plaintiff's ability to speak for lierself in her own words and tell her story. Instead, she must shape her story to fit within legal precedent and doctrine and she must conform to the symbolism of dress and demeanor, ritual, and authority. This whole system is disempowering for an injured plaintiff whose knowledge, culture, and daily life might be very distanced from legal culture.

On the other hand, busmess and large corporations fit well into the legal culture. This is especially apparent in mass tort cases against large, corporate enterprises, because much of what happens throughout the litigation process and in the courtroom is dependent upon the work, knowledge and power of lawyers, technical and scientific experts, and investigators, who are often on big corporations' payrolls. Corporations consciously plan for the contingency of potential hitigation. PETER REUTER, THE ECONOMIC CONSEQUENCES OF EXPANDED CORPORATE LIABILITY: AN EXPLORATORY STUDY (Rand Institute of Civil Justice, No. N-2807-ICJ, 1988); Rosenberg, supra note 41, at 902-05. Plaintiffs usually do not have any of these advantages. They do not know that they are going to be injured until after tragedy strikes. The larger, more widespread, and more subtle the harms and risks imposed by a defendant corporation, the inore time and expeuse required for discovery. They cannot really know if there is a "smoking gun" until they find it; and they have to find it before it is destroyed. The destruction or concealment of important corporate documents by defense counsel and defendants las characterized some mass tort hitigation. See, eg., Anderson v. Cryovac, Inc., 862 F.2d 910 (1st Cir. 1988), remanded sub nom. Anderson v. Beatrice Foods Co., 127 F.R.D. 1 (D. Mass. 1989) (in action for injuries due to contamination of inuricipal waterwells report on groundwater fiow concealed by defendant), new trial denied, 129 F.R.D. 394 (D. Mass. 1989), aff'd, 900 F.2d 388, (1st. Cir.), cert. denied, 111 S. Ct. 233 (1990); Hense v. G.D. Searle \& Co., 452 
tice includes the notion that "justice is blind"-that justice will not let differential wealth and empowerment influence her decision on the merits of the dispute ${ }^{90}$ - these differences are "ignored." 91 We are encouraged to beheve that our justice system and its courts are a public space where all citizens will have equal voices before the law, even if race, gender, class, sexual orientation, disability, or other factors disadvantage people elsewhere in our society. Complaints can be aired and justice sought, regardless of a party's status, wealth or power. Nevertheless, power clearly affects the judicial process. Time and again we see a judicial system in which power is confirmed, and the law privileges the privileged, in fact if not in theory. Yet the ideology of equality-before-the-law remains strong.

Accompanying our ideology of equality-before-the-law is an expectation that the judge and legal process somehow will intervene, if necessary, to balance the unequal power between the parties, so that justice can prevail. Judges are supposed to ensure a fair contest.92 An expectation of judicial intervention in the power dynamics seems to clash with other systemic constraints that implore a judge to be neutral, objective, and to apply universal rules that do not acknowledge the power dynamics. No matter how carefully we develop rhetoric and ideologies about equality-before-the-law, without judicial or judicial process interventions, they are false. We camiot subvert the realities of power differences by ignoring them or by pretending to employ neutral rules that are "blind" to these differences..$^{93}$ Neutral rules will at best perpetuate the status quo of power differences and its effects. ${ }^{94}$

N.W.2d 440 (Iowa 1990) (in action for personal injuries attributed to the Copper-7 IUD, defendant fined for concealing index to 12,000 documents in face of repeated discovery requests); Lord, supra note 29.

90. Corrective justice for parties who are less empowered or have been subordinated or oppressed in our society ought not be defeated by their status in the power hierarchy. We do not think that race, class, or gender statuses, for example, should hamper plaintiff' quest for justice.

91. Power inequities are ignored in the sense that they are not spoken of, but not in the sense that the inequities do not make a difference. See Frank Vandall, Judge Posner's Negligence-Efficiency Theory: A Critique, 35 EMORY L.J. 383, 405 (1986). To truly ignore these power differences and their effects, a court must alter the dynamics to eliminate their advantages or disadvantages.

92. See generally Ruggero Aidisert, The Judicial Process: Readings, MatzRials AND CASES (1976).

93. This critique is made forcefully by feminist scholars in their challenges to formal equality. See Catharine Mackinnon, Difference and Dominance, in Feminism Unmodified: DisCOURSES ON LIFE AND LAW, supra note 27; Lucinda Finley, Transcending Equality Theory: $A$ Way Out of the Maternity and the Workplace Debate, 86 CoLUM. L. REv. 1118, 1120 (1980); Christine Littleton, Reconstructing Sexual Equality, 75 CALIF. L. REv. 1279, 1282 (1987).

94. Neutral rules often replicate the original power imbalances in divorce, see Sally Sharp, Faimess Standards and Separation Agreements: A Word of Caution on Contractual Freedom, 132 U. PA. L. REv. 1399, 1405-07 (1984). Mediation in divorce and in wife abuse cases have shown that third party intervention often is necessary to equalize the power of the parties or else the stronger, 
Despite its many claims to the contrary, our justice system is not blind to wealth and power. The relationship between justice and power prevents many mjured parties from access or entry to the legal system in the first imstance. People who disbelieve the ideology of equality-beforethe-law fear that their lesser status or power will defeat their quests for justice. Others, who liave been acculturated into the ideology of equality-before-the-law, suffer cognitive dissonance when they are faced with a very different reality and lived experience. Justice is a loom for our social fabric. The ideal of equal-justice-before-tle-law informs our social consciousness, secures our political consent, and enables social coliesion across "difference," "95 thereby lending courts their legitimacy.

If parties are differently empowered and that power differential impacts on the process before the court, then the possibility of equal justice will be defeated. Therefore, we must ask how courts and legal primciples can neutralize or level power mequalities between parties, so tliat justice can be realized.

\section{Partial Solutions to Disparate Empowerment of Injured Plaintiffs and Corporate Defendants in Mass Tort Cases: Burden- Shifting and Presumptions}

As noted above, the criminal law intervenes to equalize the power of the defendant and the state before the court. ${ }^{96}$ Why shouldn't the same power-leveling principle be employed in common law mass tort?

An equal-justice-before-the-law inethod for equalizing the power of the parties requires that the burden of proof (risk of nonpersuasion and

inore powerful party wins. See Ann Diamond \& Madeleine Simborg, Divorce Mediations: Weaknesses, CaL. LAw., July 1983, at 37; Lisa Lerman, Mediation of Wife Abuse Cases: The Adverse Impact of Informal Dispute Resolution on Women, 7 HARV. WOMEN's L.J. 57 (1984); Janet Rifkin, Mediation from a Feminist Perspective: Promise and Problems, 2 LAW \& INEQUALITY 21, 21-31 (1984); Gary Weissinan \& Christine Leick, Mediation and Other Creative Alternatives to Litigating Family Law Issues, 61 N.D.L. REV. 263, 282-83 (1985).

95. As Professor Martha Minow so artfully teaches, social and justice systems should not attempt to erase or ignore difference, but should respect differences and affirm the equal dignity of all before them. Martha Minow, Foreword: Justice Engendered, 101 HARV. L. REv. 10, 16 (1987).

96. Of course this is all ideological. In fact, the state overpowers criminal defendants all the time before trial. Criminal defendants are "coerced" into plea agreeinents based on veiled threats that if they exercise their "rights," then they will end up with greater punishment. In addition, criminal defendants understand that the presumption of innocence is not necessarily accepted by judges, prosecutors, juries (and even some criminal defense attorneys). Recognizing the enormous disparity between actual practice and the ideology does not alter the rationalization for the rules. If we were able to alter the ideology about the respective power of the parties and the appropriate burdens of proof and persuasion in mass tort or product bability, then we would be making some progress even if practice lagged behind the ideology. Ideally, practice will be affected substantially by this proposed change. The ideology is important because it reflects our espoused goals and values. 
nonproduction) in mass tort cases be allocated on a case-by-case basis to the more empowered party in the dispute, subject to the particularized context and parties to a lawsuit or conflict. In initial pre-complaint or pre-trial proceedings, a court should evaluate the differential power of the parties and allocate the greater burden of proof to the more empowered party. In mass torts caused by corporate conduct, this burden inost often will fall on the corporate defendant. In addition, the presumption of "innocence" or "nonliability" should rest with the less empowered party to the litigation. In mass torts caused by corporate conduct, this presumption most often would attach to the injured party or parties.

I propose the following solution to the unequal power distribution in inass torts which would place the initial economic loss on a corporate defendant who crcated the risk of harm. When a defendant is a powerful corporation or collective organization, there should be no presumption in its favor. Instead the presumption should he with the injured party in that case. If a plaintiff is injured or subjected to risk of mjury by a massproduced product or corporate for-profit activity, after a limited showing has been made about the corporation's creation of risk to the plaintiff, a corporate actor should be required to bear the initial economic loss (medical expenses, lost wages, or imcome maintenance and special out-ofpocket damages). This presumptive hability would attach to the creation of a risk of harm during activities for private profit. It would be a rebuttable presumption. The corporate actor would have the option of exculpating itself from responsibility for the harm. The goal would not be to prejudge the dispute or give an injured victinı an unfair advantage, but rather to level the power of a corporate defendant's accuinulated or collective resources and access to knowledge so that it is inore comparable or fair with respect to a potential plaintiffs. Then parties would come before the court as relative equals.

Burden-shifting presumptions are neither foreign to courts nor to the common law of torts. Contests over burden-shifting presumptions and causation recently have preoceupied the Supreme Court in Title VII employment discrimination cases.97 ${ }^{97}$ Tort doctrines like res ipsa loqui-

97. See Wards Cove Packing Co. v. Atonio, 109 S. Ct. 2115 (1989); Price Waterhouse v. Hopkins, 490 U.S. 228 (1989). 
tur ${ }^{98}$ and alternative joint liability, ${ }^{99}$ some forms of enterprise or marketshare liability, ${ }^{100}$ and certain rules in strict products liability ${ }^{101}$ shift the burden of proof of eitlier negligence, causation, or particular facts to defendants. The difference between those teehniques and this proposal is that, under the current proposal, the burden of proof would be shifted for purposes of the entire litigation and for all elements of the cause of action after the plaintiff has made a limited "risk" showing that the corporate actor may have created a risk of liarm to which the plaintiff was exposed. ${ }^{102}$ Also, the burden would be shifted, not based on the facts peculiar to the injury or product, but rather on the comparative power,

98. See, e.g., Escola v. Coca Cola Bottling Co., 24 Cal. 2d 453, 460, 150 P.2d 436, 439 (1944); Ybarra v. Spangard, 25 Cal. 2d 486, 490, 154 P.2d 687, 689 (1944). Res ipsa loquitur either raises an inference of negligence that permits a plaintiff to get to a jury or raises a presumption of negligence that shifts the burden to a defendant to rebut, depending upon the particular jurisdiction. DAN Dobes, Torts and Compensation: Personal accountabilitry and Social Responsibility for INJuRy 173 (1985); William Prosser, W. PAge KeEton, DaN B. Dobes, Robert E. KeETON \& DAVid G. OWEN, Prosser AND KEETON ON THE LAW OF TORTS $\$$ 39-40 (5th ed. 1984).

99. Alternative joint liability shifts the burden of causation to defendants when all possible defendants are before the court and proven to lave been negligent towards the plaintiff, but it is impossible for the plaintiff to identify which of several defendants caused the harm. See, e.g., Summers v. Tice, 33 Cal. 2d 80, 86, 199 P.2d 1, 4 (1948); RESTATEMENT (SECOND) OF TORTS $§ 433 B(3)$ (1965). See also Anderson v. Somberg, 67 N.J. 291, 338 A.2d 1, cert. denied, 423 U.S. 929 (1975).

100. See, e.g., Hall v. E.I. duPont de Nemours \& Co., 345 F. Supp. 353, 374 (E.D.N.Y. 1972) (cnterprise liability theory whereby burden of proving causation is shifted to defendants where individual defendant-manufacturers cannot be identified and industry-wide standards exist); Sindell v. Abbott Labs., 26 Cal. 3d 588, 613, 607 P.2d 924, 937, 163 Cal. Rptr. 132, 145 (after plaintiff has joined a substantial share of the producers in the relevant market, the burden shifts to defendants to exonerate themselves from liability for their market share), cert. denied, 449 U.S. 912 (1980); Abel v. Eli Lilly, 418 Mich. 311, 343 N.W.2d 164 (modified alternative liability where if plaintiff joins all defendants who sold DES in relevant market, then the burden shifts to defendants to exculpate themselves), cert denied, 469 U.S. 833 (1984); Hymowitz v. Eli Lilly Co. 73 N.Y.2d 487, 539 N.E.2d 1069, 541 N.Y.S.2d 941 (adopted market share theory whereby each defendant manufacturer of DES liable for its share of the national market), cert denied, 110 S. Ct. 350 (1989); Martin v. Abbott Labs., 102 Wash. 2d 581, 605, 689 P.2d 68, 380 (1984) (alternative liability market share where plaintiff need ouly join one defendant, but if there are more, each defendant is liable for presumptive pro rata share unless defendant can prove its actual market share is less than the pro rata share); Collins v. Eli Lilly, 116 Wis. 2d 166, 197-98, 342 N.W.2d 37, 50-52 (adopting risk contribution theory, once plaintiff establishes a prima facie case and that defendant marketed the type of DES involved in the injury, defendant has burden of proving it did not produce or market the DES in the relevant market), cert denied, 469 U.S. 826 (1984). These relatively new enterprise or alternative liability theories (primarily developed in the context of DES litigation) shift the burden of proof of identity of the defendant who caused the harm from plaintiff to multiple defendants in circumstances where negligence or strict liability has been proven, but proof of identity of a specific defendant has been made impossible by no fault of the plaintiff.

101. See, e.g., Barker v. Lull Eng'g Co., 20 Cal. 3d 413, 431-32, 573 P.2d 443, 455, 143 Cal. Rptr. 225, 237 (1978) (under "risk-benefit" standard, burden of proof to sliow that design was not defective shifts to defendant once plaintiff makes prima facie slowing that defect probably caused injury).

102. Other scholars have made similar proposals. See, e.g., Richard Merrill, Compensation for Prescription Drug Injuries, 59 VA. L. REv. 1, 107-12 (1973) (proposing a form of strict liability and burden-shifting with prescription drugs). 
resources, and access to knowledge of the parties. To that extent, it should be easier to apply and predict than the traditional burden-shifting presumptions that are often more fact specific than party specific.

\section{A Feminist Exercise of Judicial and Legal Power}

Even though the state is not a party to mass tort litigation, courts (and hence the state) exercise considerable power in resolving inass tort disputes in their capacity as provider of the rules, decisions, and forums. There are two ways the judicial systein can try to alleviate problems associated with the unequal power of parties: (1) through individualized paternalistic inoves in which the court acts in an equity-like inanner, or (2) by developing rules or techniques to einpower or equalize the power of the parties. The method cliosen to deal with power imequalities affects the likelihood of just results. To date, the dominant legal approaches to the inequalities of power between parties liave been either exceptional exercises of paternalistic power (through equitable powers to protect the vulnerable) or the dominant, non-interventiomist approach ${ }^{103}$-a laissezfaire, frec inarket notion of letting the chips fall where they inay, even if that provides one party with a license to overpower the other. ${ }^{104}$ Neither

103. Professor Clare Dalton brilliantly highlights the failure of contract doctrine to intervene based on power inequalities of the parties. Clare Dalton, An Essay in the Deconstruction of Contract Doctrine, 94 YALE L.J. 997, 1106-13 (1985).

104. A laissez-faire approach to the power of the parties is widely accepted, and the power of a court to act paternalistically to protect vulnerable parties is acknowledged only in the exceptional cases.

Were we to apply Derridian insights about the hierarchized and dualistic struetures of texts and the usefulness of inverting these hierarchies, we might decide that the non-interventionist and paternalistic concepts were mutually dependent, related through the concept of differance, and that the law's privileging of the non-interventionist approach is fallacious. See JACQUES DERRIDA, OF GRAMMATology 141-64 (G. Spivak trans. 1976); JACQUes DeRridA, PositIons (1981) (threc interviews of Derrida outlining his conceptual dualism). Derrida explains that paired concepts are mutually dependent rather than separate and independent. Différance is the term Derrida uses to represent the interdependency of paired concepts and the false distinction between them. For further explanations of the idea of différance as developed by deconstructionists, see JoNATHAN Culler, ON Deconstruction: Theory ANd Criticism After Structuralism 95, 129, 162 63 (1982); Christopher Norris, Deconstruction: Theory and Practice (1982); Chris Weedon, Feminist Practice and Post-Structuralist Theory 25, 163 (1987); J.M. Balkin, Deconstructive Practice and Legal Theory, 96 YAIE L.J. 743, 752-53 (1987); Daunel Williams, Law, Deconstruction and Resistance: The Critical Stances of Derrida and Foucault, 6 CARDozo ARTS \& ENT. L.J. 359, 363 (1988).

An inversion of the privileging of a non-interventionist approach over a paternalistic approach might lead us to conclude either that courts regularly ought to employ paternalistic tecliniques, or that neither mode shonld be privileged. But when the Derridian method is combimed with a Foucauldian sensitivity to the inaterial manifestations of power and knowledge tlirough discourse, see Hubert Dreyfus \& Paul Rabinow, Michael Foucault: Beyond Structuralism and Hermeneutics 44-78 (2d ed. 1983); Michael Foucault, Power/KNowledge: Selected INTERVIEWS AND OTHER WRITINGS, 1972-1977, at 109-33 (1980); PAUL RABINow, Introduction, in The Foucault Reader 12-14 (P. Rabinow ed. 1984); C. Weedon, supra, at 107-25, and a femi- 
empowerment nor power-balancing are discussed. A feminist inquiry, in contrast, leads to questions about which approaches have been excluded froin the debates about options and why. ${ }^{105}$ Why have questions of einpowerment and power-balancing between parties been excluded in the current construction of the debates about differently empowered parties? Can we reconceptualize litigation between differently empowered parties in light of requirements of justice and equality-before-the-law?

Traditionally, if legal analysts and judges have approached this problein of unequal power they have done so paternalistically. ${ }^{106}$ Paternalisin involves making decisions or rules for others in what is determined to be their own best interest. ${ }^{107}$ Although certain commentators havc used the term "paternalisin" inore narrowly to refer only to instances where the beneficiary is coerced against her will (or her will is overruled), ${ }^{108}$ I find this narrow definition too confining. With its roots in the notion of fatherhood and acting like a fatler, 109 "paternalism" means making decisions on others' behalf to protect thein froin harm or to advance their well-being. Although the inotivation for paternalistic intervention may be altruistic, it inevitably involves an element of autonomy-deprivation for the "protected" party. 110

nist sensitivity to excluded knowledges and the partial, biased perspectives in law, see infra notes 151-52 and accompanying text, a different conclusion presents itself.

105. See Bartlett, supra notc 7, at 829; Lucinda Finley, A Break in the Silence: Including Women's Issues in a Torts Course, 1 YALE J.L. \& Feminism 41 (1989); Martha Minow, Feminist Reason: Getting It and Losing It, 38 J. LEGAL EDUC. 47, 47-48 (1988); Heather Wishik, To Question Everything: The Inquiries of Feminist Jurisprudence, 1 BERKELEY WOMEN's L.J. 64, 68 (1985).

106. See Duncan Kennedy, Distributive and Paternalist Motives in Contract and Tort Law, with Special Reference to Compulsory Terms and Unequal Bargaining Power, 41 MD. L. REv. 563 (1982) (arguing that decisionmakers use paternalist motives under the rhetoric of unequal bargaining power, although they disguise their motives as distributive or efficient); Frances Olsen, From False Paternalism to False Equality: Judicial Assaults on Feminist Community, Illinois 1869-1895, 84 Mich. L. REv. 1518, 1523-29 (1986) (arguing that the paternalisin used by the courts is a false paternalism).

107. Gerald Dworkin, Paternalism, 56 MonIST 64, 65 (1972) ("By paternalisn I shall understand roughly the interference with a person's liberty of action justified by reasons referring exclusively to the welfare, good, happiness, needs, interests or values of the person being coerced."); David Luban, Paternalism and the Legal Profession, 1981 WIs. L. REv. 454, 461 (defining paternalism as "the imposing of constraints on an individual's hiberty for the purpose of promoting his or her own good.").

108. Professor Duncan Kennedy uses a narrower definition of paternalisin that requires the decisionmaker to overrule the beneficiary's choices or preferences. D. Kennedy, supra note 106, at 572; accord Olsen, supra note 106, at 1531-34.

109. "Paternalism" is defined in the Webster's ThiRd New INTERnational Dictionary 1654 (1981) as "the principles or practices of a government that undertakes to supply needs or regulate conduct of the governed in matters affecting them as individuals as well as in their relations to the state and to each other." Paternal means "of or relating to a father." Id.

110. I do not mcan to imply that paternalism is necessarily a negative because it deprives a party of autonomy. The textual statement is inore descriptive than judgmental. 
Legal paternalism can be located in certain legislation that "protects" or "controls" people in their own best interests"11 and in doctrinal formulations or individual exercises of power by courts. Judicial (as opposed to legislative) paternalism is usually an act of noblesse oblige, a charitable gesture of mercy, a gift from the einpowered. It does nothing to equalize power, rather, it substitutes the court's power for that of the "underprivileged," "unempowered," or severely "unequal" party in a particular circumstance. For example, using concepts like unconscionability, courts have paternahistically voided contract provisions for unempowered promisors (widows, immigrants, the poor, the injured), devisors, or tenants who were taken advantage of because of their unequal bargaining power. ${ }^{112}$ These paternalistic interventions by courts have sought to benefit "underdogs," but they have done so by having the court overpower the "bully." Occasionally in tort, courts paternalistically have protected less empowered parties by imposing special or higher standards of care on those with whom they deal ${ }^{113}$ or by preventing the interposition of affirmative defenses. ${ }^{114}$ A court hears a particular case on the facts and, in its mercy, decides a point of argument or law in favor of a disadvantaged party to protect that party from abuse or overbearing. This paternalistic intervention is not bad or wrong for a court to do, but it is not the same as empowering a disadvantaged party.

I would like to emphasize a previously excluded conception of power that entails empowering others or power-balancing and examine

111. For example, laws requiring motorcyclists to wear helmets or prohibiting the use of certain drugs.

112. See, e.g., Williams v. Walker-Thomas Furniture Co., 350 F.2d 445, 448 (D.C. Cir. 1965) (court granted consumer relief from unconscionable installment sales contract with furniture company); Kugler v. Romain, 58 N.J. 522, 538, 279 A.2d 640, 645 (1971) (court willing to intervene when company specifically marketed overpriced encyclopedias to minority and low-income clients with little education); Frostifresh Corp. v. Reynoso, 52 Misc. 2d 26, 28, 274 N.Y.S.2d 757, 759 (2d Dist. 1960), aff'd in part, rev'd in part, 54 Misc. 2d 119, 281 N.Y.S.2d 964 (N.Y. Sup. Ct. 1967) (court refused to enforce unconscionable sales contract made with low-income, Spanish speaking person for over three times value of appliance). See also D. Kennedy, supra note 106; U.C.C. §2302 (1987).

113. For example, a higher duty of care is owed by common carriers and innkeepers to individual members of the public, see RESTATEMENT (SECOND) OF TORTS § 314A (1965), and courts sometimes refuse to waive duties of care despite exculpatory clauses or releases. See, e.g., Tunkl v. Regents of the Univ. of Cal., 60 Cal. 2d 92, 101, 383 P.2d 441, 446, 32 Cal. Rptr. 33, 38 (1963) (not enough evidence that releasing party acquiesced voluntarily to the shifting of risk for necessary services such as hospital care).

114. See, e.g., Suter v. San Angelo Foundry \& Mach. Co., 81 N.J. 150, 168, 406 A.2d 140, 147 (1979) (court refused to permit a contributory negligence affirmative defense in strict products liability ease), superseded by N.J. STAT. ANN. § 2A.58C-3a(2) (West 1987); Bexiga v. Havir Mfg. Corp., 60 N.J. 402, 409-10, 290 A.2d 281, 285-86 (1972) (court refused to permit a contributory negligence defense when negligent machine design created the very risk of harm that plaintiff suffered); Siragusa v. Swedish Hosp., 60 Wash. 2d 310, 319, 373 P.2d 767, 773 (1962) (court barred assumption of the risk affirmative defense in employment context). 
some consequences of making this change. I propose a feminist form of legal intervention for resolving conflicts between dramatically differently empowered parties-a type of intervention that is very different from the paternalistic variety. ${ }^{115}$ This type of intervention is designed to enhance opportunities for autonomy, dignity, choice, and decisionmaking. ${ }^{116}$ This proposed power-balancing or power-enhancing strategic intervention is an attempt to create a space in the legal world where the structures that work daily against people's personal empowerment are used instead for their benefit. The goals are to empower those who have not becn privileged and to erase the advantages of others' power privileges im situations in which lack of such privileges has been disempowering or suppressive to others. The effort to level the power differential between hitigants is not a paterualistic exercise of power, but imstead can be seen as a power-balancing or empowering move.

Professor Robin West, in her influential article, Jurisprudence and Gender, cogently distingnishes between dominant inale and female experiences of power and understandings about its use and responsibilities. ${ }^{117}$ West suggests that many women's experiences of having power (as opposed to the experiences of most men) arise in situations of grave imequalities of power, such as in parentimg or teaching, in which women often use their power to protect and guide rather than to strong-arm or control. She explains that parental (im particular, maternal) power, derived froin the power and knowledge differential between parent and child, is interpreted by its holder as a responsibility to care for the unempowered

115. This proposal is not meant to substitute for paternalistically motivated doctrine or applications of equity, but to affect the process dynamics and through them substantive justice in the courtrooin, in negotiations, and for settlement.

116. This proposal might arguably fall within what Duncan Kennedy means by distributive unotives. See D. Kennedy, supra note 106. It would depend upon whether distributive motives could aim to distribute power (rather than material resources) within one forum (judicial system) and not broadly across the economy and politics.

117. Robin West, Jurisprudence and Gender, 55 CHI. L. REV. 1 (1988). For further elaboration on this analysis, sec Robin West, Feminism, Critical Social Theory and Law, 1989 U. CHI. LEGAL F. 59, 80-81. While debates rage about whether these differences are biologically tethered, socially or psychologically constructed as part of gender, politically constructed through subordination and oppression, or some mixture of all of these, the sources of these differences are not nearly as important as the ways to which we can put our nnderstandings of thein to good use in our practices and theories of law. I work on the assumption that gender differences do exist, that they are learned, and that siuce they are learned, they can be taught, inodified and used to improve the quality of all our lives.

Let me not be misunderstood. Although I believe that our understandings and experiences of this kind of exercise of power arise out of women's experiences in earegiving to persons less enabled than they are (e.g., children, elderly, sick or imjured), I am not representing that this concept of power is unique to women or that all women understand power in this manner. 
or less-empowered child, a responsibility to teach and empower. ${ }^{118}$ Sara Ruddick makes a similar observation about maternal power and practice. ${ }^{119}$ It is the very awareness of the inequality of power that prompts or produces the responsibility to protect, to enable, and to give care, rather than to overwhelm or control. The two inodalities of power can be differentiated as "overpowering or controlling/protecting" (a masculinist model) and "empowering or power-balancing" (a femimist alternative). 120

In the inasculinist model of intervention, the general power imbalance of the parties as litigants in the court is neither addressed nor altered. The court and the rules of law do not respond to a disadvantaged party's need for empowernent nor do they balance power in the courthouse so that litigants can have equal access to or opportunities for justice. Legal paternalism does not challenge the distribution of power between parties or how it impacts on the judicial process itself.

To empower a mass tort plaintiff, a court must alleviate some of the imitial impediments to equal justice posed by the difficulty faced by a plaintiff in obtaining the necessary evidence to support ler claim for relief. 121 A corporate producer or actor putatively responsible for the harm has unobstructed access to the information. ${ }^{122}$ By shifting the burden of proof and production to the party inost capable of bearing it (by virtue of wealth, power, knowledge, and access to information), a court can balance the power of the parties in their conflict and empower the disadvantaged party in her quest for justice. ${ }^{123}$ In addition, a court can

118. Duncan Kennedy is sensitive to this parental use of power; Kennedy refers to it as "strong paternalism," and roots it in "lived intersubjectivity." D. Kennedy, supra note 106, at 638.

119. See Sara Ruddick, Maternal Thinking: Toward a Politics of Peace $82-102$ (1989) (maternal practice in societies in whicl children demand protection, nurturing, and training involves the exercise of maternal power to achieve the goals of preservation, growth, and social acceptability for one's children).

120. Both the inasculinist and feminist approaches to the use of power contain the idea of protecting the vulnerable from liarm. The distinction between power-over and empowerment has been made in other feminist literature. See STaRhawk, Truth or Dare: Encounters with Power, AUTHORITY, AND MYSTERY (1987).

121. It does not inake much difference in many cases whethcr the court uses a negligence or strict liability theory. Even for products where strict liability is apphied as a matter of course, a plaintiff must prove that the product is defective. That task can involve almost as much investigation, expertise, and lawyer time as proof of negligence.

122. A defendant's greater access to necessary information las been recognized by courts as grounds for shifting burdens. See Barker v. Lull Eng'g Co., 20 Cal. 3d 413, 432-33, 573 P.2d 443, 454-56, 143 Cal. Rptr. 225, 236-38 (1978).

123. This power-leveling approach would work just as well in a case in which the plaintiff is a large corporate organization and the defendant is a less-empowered individual. The burden of proof and production always would be placed on the more empowered party and the presumption of nonliability always would be on the less-empowered party, regardless of which one is the plaintiff or defendant. 
impose the imitial burden of paying for the economic loss resulting from the injury on the party better able or more empowered to bear the out-ofpocket expense. ${ }^{124}$

An interesting side-effect of this change of imitial responsibility for econo1mic losses imight be a greater and more immediate use of corporate political clout to lobby for socialized medical care and income maintenance for imjured plaintiffs. If corporate defendants realized from the outset they would have to advance the money for medical and lost-imcome expenses until they could go to trial and prove that the burden should be shifted, then they might take an active role in lobbying legislatures for statutory, tax-funded compensation for these victims. At the present time, their mcentive to lobby for these measures is neghigible because the mitial loss always falls on the imjured party and his or her insurance carrier. If the law presumed that the loss imitially fell on the more empowered party-in cases of mass torts and consumer products hability this party would be a corporate entity-then that party would have increased incentive to provide an alternative compensation system. Plaintiffs as a group do not have the saine kind of political power to get such measures enacted because they do not have advanced knowledge that they will be plaintiffs. Witl a change in the burdens of proof and persuasion and the presumption of nonliability, defendant corporations immediately would face imcreased potential hability, and they would seek pohtical rehef or would insure accordingly.

By power-balancing or empowering a party, the court is not interfering in the merits or substance of the controversy. This feminist approach does not "decide" the case, but rather gives the parties more equal opportunities to present their claims. If we continue with ouly the masculinist approach taken by courts, wherem they intervene paternalistically, we ignore the role that unequal power and resources currently play in the legal conflict-resolution process itself. Even with this alteration im the burden of proof and the presumption of nonliability for the plaintiff, defendant corporations in mass tort cases would be as capable of prevailing in the hitigation on the merits as they are today, but they would not be quite as advantaged in the process by their greater resources, power, or knowledge.

In summary, courts ought to employ a feminist understanding of power to empower parties in mass tort cases who face corporate oppo-

124. The Indian lower court made a similar move in response to the Bhopal tragedy when it ordered that Union Carbide pay over $\$ 190$ million into a fund for the victims prior to any trial or finding of liability. See Andrew Blume, Rita Jensen \& Marianne Lavelle, Carbide Blasts Bhopal Order, Nat'l L.J., Apr. 18, 1988, at 6, col. 1., Stephen Adler, Bhopal Ruling Tests Novel Legal Theory, Wall St. J., May 18, 1988, § 2, at 33, col. 3. 
nents with greater resources, knowledge, power, and access to information. One method for accomphishing this power-leveling or powerbalancing function is through burden-shifting rules that place the risks of nonproduction and nonpersuasion on empowered corporate defendants rather than on injured plaintiffs. Another part of this strategy is the use of a hability-shifting rebuttable presumption, whereby once the plaintiff has made a simple "risk" showing that a corporate defendant created a risk of harm to which plaintiff was exposed, the defendant is hable for all of plaintiff's economic damages (medical, rehabilitative, loss of wages, specials). The law could require an immediate remedy from the corporation before any finding of liability. ${ }^{125}$ If the corporation betieves the result to be imjust, it could mitiate legal action, and in the event that the corporation wins the legal action, the plaintiff will have to repay the defendant. In addition, if the presumption of nonliability is with the tort victim or the less empowered party, ${ }^{126}$ and the more powerful party must pay for the loss and wait for the result of the litigation to recoup those payments, then defendants might not be motivated to delay ${ }^{127}$ and resolution might be achieved more quickly. This also would equalize the parties' bargaining positions for settlement. ${ }^{128}$

Empowermg victims in their struggle for compensation from corporate tortfeasors will not, in and of itself, eradicate the sources of the hability crisis. One of the sources of the crisis is a skewed account of responsibility. In the next section, I mvestigate the meanings of responsibility in tort law and propose a revision of our understanding of responsibility.

125. See Adler, supra note 124.

126. It is imaginable that with the defendant's burden of proof and the plaintiff's presumption of nonliability in mass tort cases, a court might require a defendant to escrow some funds for the plaintiff's benefit, and may entitle plaintiff access to some of those funds for health, maintenance, and even litigation expenses as needed. This would encourage defendant corporations to accelerate resolution of the conflicts rather than delay, whicl is their current strategy. Or the law could require that defendants' employee compensation and health plan cover the victuns after an initial probable cause showing has been made.

127. See Rosenberg, supra note 41, at 902-03; see also Jan Schlictmann, Eight Families Sue W.R. Grace and Beatrice Foods for Poisoning City Wells with Solvents and Causing Leukemia, Disease, and Death, in Proof of Causation and Damages in Toxic Chemical, Hazardous Waste, and Drug CASEs 211 (Practising L. Inst. 1987, Litigation Series No. 341) (illustrates use of delay and legal maneuvers by corporate defendants). Defendants are usually unaffected by trial delays or positively affected because the need for money encourages plaintiffs to settle early for less than they could have won in court, and defendants have the use of their money for their operations and continued growth during the period of delay.

128. For a discussion of the effects of unequal power in settlement, see Owen Fiss, Against Settlement, 93 YALE L.J. 1073, 1076 (1984). 


\section{Thoughts About the Meaning of Responsibility in Mass TORTS CAUSED BY CoRPorate Defendants}

"Responsibility" and "responsible" have several different meanings. ${ }^{129}$ I want to suggest that the meaning of "responsibility" in tort law ${ }^{130}$ is too thin. ${ }^{131}$ We can improve the tort system by rethinking the values underlying legal responsibility and making legal responsibility more multi-dimensional, more contextual, and more informed with imsights from feminist theory. In order to think more clearly about the multiple meanings of "responsibility," I have divided the meanings into subcategories. ${ }^{132}$ By exposing various interpretations of the concept, I hope to illustrate that certain meanings of "responsibility" have been omitted or excluded from legal discourse and to explain how our legal world can benefit from their mclusion. I recommend the expansion of our legal account of responsibility to include a holistic, needs-based, caregiving response. Although it may seem as if this proposal only adds a ineaning or two to the existing base, I intend this proposal to be more far-reaching. This change in our understanding of responsibility requires

129. Kate Pecaroviclı las assembled an extensive recent bibliograplyy on responsibility (for materials produced from 1961-1985) that illustrates the depth and multiplicity of understandings of responsibility as an ethical and legal concept. Kate Pecarovich, Bibliography on Responsibility, LAw \& CONTEMP. Probs., Summer 1986, at 237.

130. BLACK's LAw Dictionary 1312 (6th ed. 1990) defines responsibility as "[t]lle obligation to answer for an act done, and to repair or otherwise make restitution for any imjury it may have caused." Responsible means "liable; legally accountable or answerable." Id. at 1312.

This Article is limited to a discussion of the idea of responsibility within the context of the legal system and, in particular, within tlie context of torts. Arguments have been made and accepted that responsibility as a moral or etlical concept is distinct from responsibility as a legal concept. Perliaps one of the most notorious advocates of that position was Justice Holmes. I am unconvinced that law and morality slould be (or are) autonomous or semi-autonomous disciplines, but $I$ avoid that debate here. For purposes of this Article, I assume that it makes sense to write about responsibility in the legal sense only.

131. See Clifford Geertz, Thick Description: Toward an Interpretive Theory of Culture, in THE INTERPRETATION OF CULTURES 3, 6-7, 9-10 (1973) (relying on the work of Gilbert Ryle for use of the terms "thick" and "thin").

132. Although I do not use lier categorizatiou, Carol Gilligan has identified different notious of responsibility. Carol Gilligan, Remapping the Moral Domain: New Images of Self in Relationship, in Mapping the Moral Domain: A Contribution of Women's Thinking to Psychological Theory AND Education 3 (C. Gilligan, J. Ward, J. Taylor \& B. Bardige eds. 1988) [hereinafter MAPPING THE Moral Domain]. She explains:

When asked "What does responsibility mean to you?" a high scliool student replied: "Responsibility means making a commitment and tlien sticking to it." This response confirms the common understanding of responsibility as personal commitment and contractual obligation. A different conception of the self and of morality appears, lowever, in anotlier student's reply: "Responsibility is when you are aware of others and you are aware of their feelings. ... Responsibility is taking cliarge of yourself by looking at others around you and seeing what they nced and seeing what you nced . . . and taking the initiative." In this construction, responsibility means acting responsively in relationships, and the self-as a moral agent-takes the mitiative to gam awareness and respond to the perception of nced. Id. at 7 (footnote omitted). 
us to reconsider how the law remedies personal mjuries. It requires a badly-needed paradigm shift in the values and assumptions of tort law from a vision of responsibility rooted in atomistic mdividuals and commodity exchange to one rooted in caregiving - an account that reflects a recogmition that human beings are interdependent. ${ }^{133}$ In order to achieve this end, the meaning of responsibility in law would include a commitment, in advance of harm, to protectimg and caring about the health and safety of other people. In the untoward event of harm, it would mean taking care of those harmed - that is, personally and interpersonally responding to the needs of harmed people. ${ }^{134}$

Tort law has been weighted down by a language and value system that privilege economics and costs. Every time there is an mjury, we determine legal responsibility by asking about the dollar and efficiency costs of paying for the harms and/or of avoiding them. Questions of cost have consistently been our first or second inquiry in cases of mass torts by corporate defendants.

As harms from inass tort have become inore widespread, legal analysis in tort law has become desensitized to the imdividuals and groups of people harmed. The more people who are mjured or subjected to the risk of mjury, the more tort law dehumanizes people generally, views them as statistical risks, and sees their mjuries as costs of economic growth and progress. If this kind of legal thinking is mconsistent with our core values, we must reject it outright as violative of human digmity and equality. Instead, we can require corporate defendants, corporate officers, and courts to be more socially and personally responsible.

\section{A. Meanings of Responsibility}

Responsibility can be divided temporally into two types of categories: pre-event (prevention-based) ${ }^{135}$ responsibility and post-event (response-based) responsibility. Within these broad categories there are subclasses of responsibility, some of which are used regularly in legal discourse, and others that seem wholly or partially moperative in law. One of tort law's failings is that it does not contain these previously excluded or undervalued meanings of responsibility.

133. There is a conservative human tendency to dismiss major changes as unworkable and to prefer the status quo. I hope that you, my reader, will fight that impulse and read with an open mind and sense of possibility.

134. I would equate "taking care of" with Sara Ruddick's definition of maternal thinking and practice. See S. RUDDICK, supra note 119, at 10-12.

135. In utilizing the word "pre-event" for the responsibility to take care of something before it happens, I was tickled to discover its connection to the word "prevent." 
The pre-event account of responsibility is important because it indicates who ought to be held responsible if something occurs. ${ }^{136}$ Pre-event or prevention-based responsibility is tied to the notion of power. ${ }^{137}$ The power to decide and take action entails a responsibility for the decisions made and action taken (or not taken). ${ }^{138}$ With power comes responsibility. They are inseparable. Prevention-based responsibility in mass tort derives from the power to choose (im a human agency sense) ${ }^{139}$ to impose risks on the health and safety of others or to perform activities that cause harm. ${ }^{140}$ One who "responsibly" exercises this power chooses to prevent harm, to minimize or eliminate risks to others created by activities or products, to gather information, to advancc learning about the consequences of corporate actions, and to stress the values of health, safety, and human dignity. In wanting people to act inore responsibly, we want them to choose to act with more care and reflection about the possible effects of their conduct and decisions on others. This is particularly true in dealing with potential harms caused by the actions of corporations. For-profit corporate activities are conducted with considerable input and pre-planning, which affords corporations more opportunities for intervention before harm is caused. We want this exercise of power to occur before there is harm (pre-event), so that there will be no harm.

Corporate executives and people within organizations must take responsibility for the decisions and actions of their organizations, whether or not they had direct knowledge. It is the power to have knowledge, the

136. The prevention account of responsibility also includes traditional attributive, causal notions of responsibility in the factual-cause sense. Although the use of the term "attributive" has soine roots in H.L.A. HART \& A. M. HONORE, CAUSATION IN THE LAW 23 (1959), I do not mean thereby to unply Hart and Honore's distinction between attributive and explanatory causation. For an elaboration of that distinction, see Witt Dray, Causal Judgment in Attributive and Explanatory Contexts, LAw \& ConTEMp. Pross., Summer 1986, at 13. Because the focus of this part of my essay is on the post-event nature of responsibility, I will leave the inultiple methods by which we assign "responsibility" to a party for another day.

137. If you have the power to decide or choose how activities will be conducted or the authority to "control" people or situations, you are responsible for the consequences of your decisions and the actions of those under your "control." Power, authority ("control" and "charge"), and choice are precursors to responsibility in the pre-event or prevention sense.

138. The law is willing to impose hability, even criminal hability, upon a person with this kind of power. See, e.g., United States v. Park, 421 U.S. 658, 669 (1975) (CEO held hable for sanitation problems in one food warehouse in his national company, even though it was under the direct management of other people in a distant city).

139. See, e.g., JeAN-PAul SARTre, BeIng AND Nothingness 216-18, $617-28$ (1956).

140. There are many problems with the relationship between the idea of responsibility and agency that need to be addressed, but to delve into these problems would sidetrack this discussion. This notion of responsibility seems to entail the idea of a pre-existing subjectivity or autonomous self-in the liberal sense-that has freedom to make choices rather than being controlled or constructed by structures. Again, this is too large and distracting an issue to flesh out here, but I will own up to an acceptance of some notion of human agency that is compatible with a possibility of chosen resistance to power structures. 
power to access necessary information, the power to control or authorize others to act, the power to choose (rather than be chosen for), the power to participate in democratic decisionmaking, and even the power to delegate one's power to choose, that carries the responsibility. ${ }^{141}$ To compel people imbued with this power to take responsibility for the consequences of their actions and decisions, mass tort law as well as criminal law inust be constructed in a manner that imposes personal hability on the individuals with the power to inake decisions or select among actions. ${ }^{142}$ The process of requiring people to take responsibility also requires that the corporation as a whole be held responsible.

But once responsibility for certain consequences can be assigned based on pre-event exercises of (or failures to exercise) power to promote the health, safety, and well-being of others, what is required of the responsible party by way of response? The post-event meanings of responsibility are woven through with the word "response."143 There are two types of response- a "inaking amends" or reparations component and a caregiving component. The reparations-form of responsibility means making amends, or payments. If you are responsible for a bill or debt or for damage to soineone's car, it means first that you caused or incurred the obligation (pre-event), and second you have a duty to make the payinents or pay for the repairs (post-event reparations sense). In inass tort law responsibility means monetary reparations. Legal responsibility in tort translates into an obligation to inake reparations-to compensate or to pay. ${ }^{144} \mathrm{~A}$ tort victim entitled to reparations can invoke the power of the state to enforce this payinent. According to tort law, though, payinent fulfills the legal responsibility and the tort victim should ask for nothing 1nore. ${ }^{145}$ Equating legal responsibility with the payment of inoney is grounded in two implicit assnmptions: (1) Legal responsibility and paying inoney are coextensive; and (2) the harms suffered by injured

141. See Park, 421 U.S. at 672.

142. If tort law only holds "responsible" those people who are responsible in the causal sense and not those who have responsibility based on the power or choosing sense, it will be inadequate to its assigned task of deterrence or prevention of harmful consequences. Part of the power to produce products and create risks for profit includes responsibility for the care and well-being of those who might be affected by the exercise of that power.

143. WEBSTER'S THIRD INTERNATIONAI DICTIONARY 1935 (1981) defines response as, "1. an act or action of responding (as by an answer): a responsive or corresponding act or feeling: a responding to a motive force or situation."

144. If conduct was particularly heinous, wilful, wanton or malicious, meeting this responsibility might also involve paying punitive or exemplary damages. See, e.g., Grimshaw v. Ford Motor Co., 119 Cal. App. 3d 757, 174 Cal Rptr. 348 (1981).

145. Only in the exceptional case can a tort victim get injunctive relief. 
persons can only be compensated in money. ${ }^{146}$ These assumptions present incoinplete images of human experience and provide pathetically inadequate support for an entire law of personal injury.

Post-event responsibility ought to mean more than making reparations. A different notion of responsibility arises out of our interconnectedness as human beings, and it has to do with responding to the needs of someone through interpersonal caregiving - it means "taking care of." Although this account of responsibility seems connpletely absent froin the law, it remains central to our life experiences. An example of a social ineaning of responsibility can help to explain the need for additional understandings of post-event responsibility in law. For two reasons, I will use an example of a close, imterpersonal relationship-that of parent and child. ${ }^{147}$ One reason was hinted at before with respect to different exercises of power and the relationship between power and responsibility. ${ }^{148}$ Parents are responsible for the health, safety, and wellbeing of their children, in part because they have far greater power within that relationship and because they have greater power with respect to the outside world to negotiate for their children's benefit. ${ }^{149}$ Corporate entities that mass-producc products or conduct risk-creating activities leading to mass harms also have far greater power than the individuals they harm both within the relationship and with the outside world. Perhaps if we could determine some of the meanings of responsibility associated with parental power, then we also could learn things about the ineanings of responsibility associated with power in other contexts.

The second reason I am using a family relationship as an example is because it can potentially give us access to perceptions about responsibility that traditionally are absent in market-related contexts. Our understandings about responsibility, law, and power in the legal and commercial worlds were formed in an environment that excluded woinen. ${ }^{150}$ Feminist method invites us to examine systems of knowledge and power (like law) for biases and to reconstruct them with valuable aspects of excluded perspectives. ${ }^{151}$ To understand what women's per-

146. In Part II, I criticized translating injury and justice into money terms. That critique is bound up with this call for a new understanding of responsibility and hence new remedies and responses to the needs of the imjured.

147. It would be just as useful to study the relationship between adult children and their frail and elderly parents. See David Biegel \& Arthur Blum, Special Issue: Aging and Family Caregivers, 13 J. APPLIED Soc. SCI., Fall-Winter 1988-89, at 1-8.

148. See supra notes $103-21 \& 135-43$ and accompanying text.

149. See S. RuDDick, supra note 119, at 29-40; West, supra note 117, at 27-28.

150. Bender, A Lawyer's Primer, supra note 7, at 6.

151. See Bartlett, supra note 7, at 837-49. 
spectives might lend to ineanings of responsibility in law or the market, we must find environments where women have exercised some responsibility and power. Even though women often have subordinate roles in families, at least they are overtly present in them. And vis-a-vis children, women often do have power. ${ }^{152}$ Examinations of the exercises of that power might help us rethink appropriate meanings for responsibility in the legal context. If legal thinkers are interested in learning how women's experiences and knowledges can be used to reconstruct our legal world, the family is an appropriate starting point for study.

Admittedly, there is something very different about relationships within a family or between friends and relationships between strangers or casual, business acquaintances. The affection, love, and intimacy that characterize familial and friendship relationships are absent froin corporate relationships with a public that is placed at risk by corporate activities. We cannot expect the caring and caregiving behavior in families that flows from love to apply to harm-causer/nnass-tort victim relationships. Nevertheless, corporate harm-causer/mass-tort victim relationships are analogous to those within the family to the extent that they involve responsibility.

Family members have an initial interpersonal responsibility of care for one another. At a minimnm we understand this responsibility as an obligation to take care of or care for a family ineinber who is unable to care for herself. Likewise, once the legal system determines that a corporation is hable or responsible for a harm, it has an obligation to remedy the harm and to take care of the people harmed. In both cases one party ends up with responsibility for another. Even though the source of the responsibility for a family member differs from the source of responsibility in a corporate-victim relationship, once responsibility attaches its source might no longer be especially relevant to its content. I would like to explore the coinplex nature of that responsibility. By shifting to a post-event meaning of responsibility that includes both a reparations sense and a caring sense, we can alter the way that the legal and corporate worlds function.

People responsible for the care of children understand that responsibility to and for those children involves a great deal inore than money. Money might buy some of the things children need, but it cannot figure out what they need at any given time or in any given context or plan how to provide for those needs. Money doesn't listen to children, soothe their fears, show them affeetion, teach thein values, or socialize them. People must take interpersonal responsibility for these activities-the planning,

152. See S. RuDdicK, supra note 119. 
organization, and forethought, the time and emotional sharing, and attention to needs and contexts. These activities are an important part of what responsibility means in interpersonal relationships. It might include taking financial responsibility, but that aspect of responsibility is just a piece of the whole.

There is much talk in our society about encouraging fathers to take responsibility for their children. This is particularly true in the cases of divorced, separated, and unwed fathers. ${ }^{153}$ If they are responsible for the children's birth (in the causal or power sense), then their responsibility (in the post-birth or post-event response sense) is a continumg commitment or obligation to "take care of" tlie children. But what do we mean by that use of the concept of responsibility?

In a legal sense, we mean inaking fathers pay child support. This sense of responsibility is analogous to paying debts incurred or paying for the cost of "repairs." In tlie reparations or amendatory sense, our legal system claims to be making fathers act responsibly by making them pay. ${ }^{154}$ But when we are not limiting ourselves to the legal meaning, is this what we mean when we say that parents have a responsibility for tlieir children or family members have a responsibility for each other? Responsibility also means taking care of, giving care to, and caring for. ${ }^{15 s}$ Being responsible for children means helping them grow into functioning, competent adults. To take care of family members, friends, children, or the injured, caregivers must give primary attention to others' needs. There is physical, emotional, and planning work involved im caregiving. People must help and support one another-it is part of our makeup as interconnected, inutually dependent beings.

\section{B. Legal Responsibility as "Taking Care of"}

The meaning of responsibility in the law must include this notion of interpersonal caregiving and needs-responsiveness. This meaning of responsibility is explicated in the work of femmist scholars, particularly the

153. See David Chambers, Making Fathers Pay: The Enforcement of Child Support

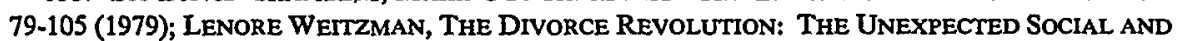
ECONOMIC CONSEQUENCES FOR WOMEN AND CHILDREN IN AMERICA 262-64 (1985).

154. If responsibility is solely paying money, then one can transfer family responsibility by having someone else pay the money owed. In fact, a cornerstone of our tort system is rehance on liability insurance to assume responsibility for paying reparations or monetary compensation legally owed to victims. I do not intend my argument to detract from the advantages of third-party liability insurance in providing compensation to those mjured. I do think, however, that the ability to purchase liability insurance in advance of harm distances individuals from the harms they have caused in a way that diffuses personal responsibility.

155. Professor Nel Noddings distinguishes between taking care of and caring for. NEL NODdings, CARING: A Feminist ApPRoach to Ethics aNd Moral Education 9-16 (1984). 
studies of moral development by Carol Gilligan and her associates. ${ }^{156}$ Gilligan's work has provided a foundation to a large portion of feminist scholarship. ${ }^{157}$ I would like to borrow some of her insights to further develop this notion of responsibility.

Professor Gilligan noted that the standard method of evaluating moral developinent based on open-ended answers to hypothetical moral probleins was not attuned to the multiple perspectives expressed by subjects. ${ }^{158}$ Popularly used and respected psychological measuring tools valued answers from the perspective she called an ethic of rights or ethic of justice. These tests concluded that moral reasoning was inore advanced if it was based on abstract principles (like equality, justice, fairness), objective and universal rules, fair fornal procedures, and the balancing of hierarchical rights (property, contract, duty). Gilligan contrasted the ethic of rights/justice with another ethic that had been excluded, submerged, or undervalued by contemporary psychological ineasures. This different approach or different voice was founded on an ethic of responsibility and care. Gilligan claimed that these different "voices" (of rights/ justice and responsibility/care) depended greatly on different perceptions of hunian relationships and ways of regarding others.

Nona Lyons pursued Gilligan's research and found two distinct perspectives of self, relationships, and morality-the separate/objective self and the connected self. 159 The separate/objective self is autonoinous in relation to others. It views relationships through a reciprocity perspective, which considers others as one would like to be considered, and assunies that others are the same as oneself. Conflicts are thus mediated through rules (primarily of equality) and grounded in roles that are de-

156. Carol Gilligan, In a Different Voice: Psychological Theory and Women's Development (1982); MAPPING THE Moral Domain, supra note 132.

157. See, e.g., Bender, A Lawyer's Primer, supra note 7; Bender, Feminist Solidarity, supra note 7; Finley, supra note 93; Kenneth Karst, Woman's Constitution, 1984 DuKe L.J. 447; Carric Menkel-Meadow, Portia in a Different Voice: Speculations on a Women's Lawyering Process, 1 BERKELEY WOMEN's L.J. 39 (1985); Ann Scales, The Emergence of Feminist Jurisprudence: An Essay, 95 Yale L.J. 1373 (1980); Suzanna Sherry, Civic Virtue and the Feminine Voice in Constitutional Adjudication, 72 VA. L. REV. 543 (1980). For a strong critique of Gilligan's work, see Joan Williams, Deconstructing Gender, 87 Mich. L. REv. 797 (1989).

At this point in time, Gilligan's metaphor of voice has been overworked and sounds almost tinny. Despite this devaluation, I think that there are very deep and important insights in her work and its overuse may cause it to be too easily discarded. For an elaboration of iny position on the usefulness of Gilligan's thesis in law, see Bender, Feminist Solidarity, supra note 7. Professor Gilligan is working to overcome some of the original shortcomings in her studies.

158. Carol Gilligan, Adolescent Development Reconsidered, in MAPPING THE Moral Domain vi, xxxiv-xxxv, supra note 132. In particular, she focused her criticism on Laurence Kohlberg's multi-stage model. See LaURence Kohlberg, The Psychology of Moral Development: ESSAYS ON MORAL DEVELOPMENT (1984).

159. Nona Lyons, Two Perspectives: On Self, Relationships and Morality, in Mapping THE MORAL DOMaIn 21, supra note 132. 
rived from obligations and duties. ${ }^{160}$ The connected self, which is interdependent in relation to others, experiences its relationships through responses to otliers in their terms-e.g., alleviating their burdens, hurt, or suffering. Conflicts are mediated through the activity of care (i.e., focused on maintaining connection and caring in relationships) and grounded in interdependence and interconnectedness. ${ }^{161}$ The response and care perspective requires seeing otliers in tlieir own terns, contextually, and it assumes that others are different from oneself. ${ }^{162}$ Carol Gilligan and Jane Attanucci distinguished between these foci as follows:

A justice perspective draws attention to problems of imequality and oppression and holds up an ideal of reciprocity and equal respect. A care perspective draws attention to problems of detachment or abandonment and holds up an ideal of attention and response to need. Two more injunctions-not to treat others unfairly and not to turn away from someone in need-capture these different concerns .... Since everyone has been vulnerable both to oppression and to abandonment, two moral visions-one of justice and one of care-recur in hnman experience. ${ }^{163}$

Both Gilligan and Lyons hinted that these different perspectives were associated witl gender - that is, women more dominantly expressed the care/response focus, and men expressed themselves more often in ternns of justice or equality/rights. ${ }^{164}$ Gilligan and Attanucci did a later study to explore gender associations with these moral orientations. ${ }^{165}$ Their preliminary results indicated that both men and women express concerns about justice and care, but they also found that "people tend to focus on one set of concerns and minimally represent the other."166

Both perspectives are important in resolving tort disputes, but the different voice that is more common in women is practically non-existent im tort law. Because tort law was created by men (as the only participants in its writing, thinking, and practice for many years), it is not surprising that an ethic of rights, which seems to be a controlling male

160. See id. at 33.

161. See id. at 33-35.

162. See id. at 34 .

163. Carol Gilligan \& Jane Attanucci, Two Moral Orientations, in id. at 73, 73-74.

164. See id. at 73, 84; Lyons, supra note 159 , at 39 .

165. See Gilligan \& Attanucci, supra note 163, at 73 .

166. Id. at 82. The problein with the simultaneous co-existence of these perspectives is that they seem to contradict one another:

The tension between these perspectives is suggested by the fact that detachment, which is the mark of mature moral judgment in the justice perspective, becomes the moral problem in the care perspective-the failure to attend to need. Conversely, attention to the particular needs and circumstances of individuals, the mark of mature moral judgment in the care perspective, becomes the inoral problem in the justice perspective-failure to treat others Id. fairly, as equals. 
ethical paradigm, dominates tort analysis. Because men devised tort laws to apply to themselves, because the ethic of rights involves an implicit assumption that others are the same as oneself, and because men frequently viewed people as separate but "socially contracting" huinan beings, legal theorists looked for solutions to conflicts that respected separation and formalized, distanced interactions. Finally, because the men who crafted tort law were scholars, judges, and practitioners who were rarely responsible for interpersonal caregiving, they were in socially-constructed positions that defined their responsibility financially. Thus, tort law's definition of responsibility is financial. The men writing and thinking about tort law tended to universalize their experiences and concerns (failing to appreciate the existence or wisdom of other perspectives) and consequently developed a limited, incoinplete definition of "legal responsibility." In its search for objective, neutral, abstract, and umversal formulas for imposing responsibility, tort law became fixated on money damages.

An ethic of responsibility and care, based on perceptions of human beings as interconnected and mutually dependent, would enrich our legal post-event understanding of responsibility. This perspective understands responsibility contextually, as responsiveness to the other's or victim's particularized needs and imterdependencies. This meaning of responsibility has dominated women's ethical paradigms. Since women function (or at least functioned) in family and interpersonal caregiving contexts, perhaps we can learn what responsibility involves from some of the tasks that women perform within families. ${ }^{167}$ From there, we can see how this interpersonal, caregiving meaning of responsibility might apply in tort law.

There is a lot of emotional work to caregiving and being responsible. ${ }^{168}$ The work involves physical and emotional care. Caregiving responsibility imvolves direct interpersonal tasks, rather than delegation, and it is time-consuming, emotionally involved, freedoin-limiting (in that one must often be there in person rather than pursuing other interests), energy-draining, demanding, rewarding, and essential to humnan survival. This interpersonal responsibility necessitates sharing time, attention, and consciousness in a manner completely ignored by the legal system.

167. Women's family caregiving tasks involve more than the care of children and spouses. Emily Abel makes clear that adult daughters have been the primary caregivers for frail, elderly parents and women have been the primary caregivers for the elderly generally. Emily Abel, Adult Daughters and Care for the Elderly, 12 FEMinist Stud. 479, 483-85 (1986).

168. See arlie Hochschild, The Managed Heart: The Commercialization gf HuMAN FEELING ix-x (1983) (recognizing the concept of emotional work or labor). 
Currently in tort law, when we hold a defendant legally responsible for the harm caused, we make the defendant pay. This is very similar to what we do to absentee fathers when we hold thein responsible. And paying is important. The money is necessary for survival and to have access to opportunities in our society. But when a tort victim is injured or incapacitated, a great deal of caregiving work is necessary ${ }^{169}$ no inatter how much money is paid. The burden of this caregiving work traditionally falls on the family and friends of the imjured, on spiritual communities, or on people hired to do soine of these tasks-usually lower class women who are paid too little and given no prestige for this vital work. This responsibility is not deened to be the responsibility of the tortfeasor.

Tort law could result in corporations and corporate officer defendants taking inore interpersonal caregiving responsibility. First, common law tort theory would have to acknowledge that financial responsibility alone is inadequate for legal responsibility, as I have argued above. A feminist voice of responsibility, ${ }^{170}$ which includes emotional, caregiving work, has not been rcadily translatable into money, so tort law has basically ignored it. Tort law, as currently constructed, has been unable to imagine another mediun of value. Common law tort must carefully reconstruct its understanding of injury so that it includes both financial loss and a recognition that injury is an einotional, physical, and spiritual event. New kinds of reinedies inust be developed-remedies that respond to victims' needs for community, care, and relationships, and rem-

169. The needs of injured victims vary according to particularized contexts, but interpersonal caregiving responsibility might include: inaking doctor appointments and taking the victims to that appointment, taking thein to therapy, and inonitoring their health care; providing transportation and inedical equipment to make them mobile (e.g., wheelchairs), and altering living spaces to accommodate new physical needs; shopping, food preparation, and hoine repairs; managing their financesmaking sure they don't lose their jobs or educational opportunities, paying bills, and helping them get benefits to which they are entitled; time-sharing and keeping company in hospitals; offering ennotional support-hand-holding, tear-wiping, distracting thein from pain, lifting their spirits, bearing their anger, depression, resentment, and hatred.

These are just a few samples of the many different kinds of interpersonal earegiving tasks that must be done. How can the legal system hold corporate defendants responsible for soine or all of these activities, which inevitably follow from serious physical and psychological injury? How can we make those who cause harm take this kind of interpersonal, caregiving, needs-based responsibility?

170. I would like to reemphasize that labeling this "feminist" does not inean it occurs in all females, or that it does not occur in men, or that it is biologically linked, or that it is essential or fixed. See generally Bender, Feminist Solidarity, supra note 7; Leshie Bender, Sex Discrimination or Gender Inequality?, 57 FordHAM L. REv. 941 (1989) [hereinafter Bender, Sex Discrimination]. I do inean it has been socially and psychologically constructed in our culture as part of the woman's role or expected behavior. The historical fact is that these tasks have been assigned to woinen in the past and that they have shaped our gender construction of the feminine. In arguing for the paradigm shift in our legal value systen, I ain arguing for a paradigm shift in our legal value construction as well. 
edies that require corporate officers and responsible individual defendants to perform the physical and einotional caregiving work. ${ }^{171}$ After they are adequately trained, individual defendants, corporate officers, and einployees who cause harms (in the pre-event responsibility sense) could be required to provide caregiving services to their victims (or persons similarly situated). ${ }^{172}$ Defendants who have caused harm in their corporate roles will have to make personal sacrifices. ${ }^{173}$ The corporations that einploy them will have to sacrifice some of their services during the day. Profits, productivity, and efficiency will be affected, but if we start from a premise of intercoimectedness as the human condition and understand the necessity for responsibility and care, efficiency, and productivity must take a second seat.

The second way in which tort law can force corporate defendants to assume more needs-based responsibility is if the tort system acknowledges that when an aceident or harm occurs, victims hive with the consequences every day. Even though the injuries were not the victims' fault, they must be in touch with the reality of the harm all the time. Defendants who are responsible for harms should have the same experience; they should be required to respond to those harms for as long as the innocent victims suffer. It is not "punishment" for the defendant to have to continue to perform caregiving in response to the harm caused, any more than it is "punishment" for families of victims to have to do it or the victim to have to cope with the contimumg effects of the injury and harm. It is life. It is being hunıan, social, intercomiected, and "responsi-

171. Defendants who are inexperienced in caregiving inay nced to be trained in how to do physical caretaking to provide emotional care and support, to focus on another's needs, and to respond to them. How can you teach soineone to give care? This task may be difficult, but we do it every day in training children and in training students or apprentices in caregiving professions. The more complicated question is whether care by someone legally forced to provide it would be worse than no care at all. Would it feel demeaning and awful to the recipient? It is difficult enough to accept ideas like Rousseau's about forcing people to be free: What about forcing people to give care? We need to think seriously about what this really means, how it could be accomplished, and the effeets it would have on the victims or recipients of this kind of care.

Maybe it is not giving care that we ought to require of tortfeasors, but performing some of the traditional caregiving functions to alleviate the burden on family and friends. The point I want to emphasize here is that as difficult as it might be to conceptualize requiring care or caregiving behavior from mass tortfeasors, by not requiring this kind of interpersonal responsibility from defendants, we impose these responsibilities on family members or loving friends. It does not go away because we do not require defendants to do it. It is just silenced.

172. It certainly is possible that a particular victim would not want to see or be with the person who had caused her the harm she suffers. In that case defendants may be required to take interpersonal caregiving responsibility for a different, but similarly situated person, whereas other defendants might take some interpersonal caregiving responsibility for the first victim.

173. I realize that in mass tort situations, it will be impossible for harmcausers to care for caeh of the vietims, because the extent of harm and numbers of victims are so great. Whatever care can be given will result in more than there would have been. 
ble." Unlike the victim, the responsible party does not have to cope with the injury and its consequences for twenty-four hours a day, but each day, every day, she ought to be required to do something in response to the victim's suffering.

Third, the tort system will have to undergo a nnore general paradigm shift with respect to values and responsibility. We need feminist (re)torts to help change the dominant ideology from individualist to imterconnected. We need to shift froin a rights-based focus to a focus on both care and rights/justice, froin power-over to empowering, from the priority of the market and money to a priority of personal relationships, health, safety, and human dignity in deciding personal mjury disputes. The solution is not to substitute one paradigm for another, but rather it is constructing a new paradign that inelds the valuable components of both approaches.

If making mdividual defendants within corporations take personal responsibility for the harms they cause is a goal of tort law-and I would argue it should be a primary goal-then those defendants inust not be able to pay someone else to do caregiving tasks for them. This aspect of responsibility ought to be non-delegable. It is the personal, time-consuming, responsiveness-to-particularized-needs-of-others kind of responsibility that must be acknowledged and imposed both on individuals and on roles within the corporate structure even if the "culpable" officers have departed. The corporation as an entity will also be fulfilling its direct, interpersonal responsibility when it sacrifices soine of its executives' and employees' time everyday to do this kind of caregiving work.

I am the first to admit that there are a lot of questions with this model. How can we inake people care? How can the law enforce this kind of responsibility? Is required caregiving worse than no care at all? Who as a victim would want the harm-causers personally imvolved in their hives? How inuch time and energy should a harm-causer devote to this kind of caregiving, considering she must still be able to keep her job and meet her own family obligations? It must be remembered, though, that these ideas are proposed as a rethinking of our legal organization and expressed values. In order to implement them, we may need to change the structure of the workplace to perimit people to spend inore time in direet, imterpersonal caregiving. ${ }^{174}$ But change inust begin somewhere. If we agree that money is madequate to salve the pam and loss of victims, and inoney has proved inadequate to deter the creation of nondemocratically imposed risks and harms on innocent members of the public, then we have a compelling need for a reimagined approach. Ma-

174. See, e.g., Bender, Sex Discrimination, supra note 170, at 949. 
jor paradigmatic shifts in our values or social organization are very difficult to imagine. We are so inculcated with the dominant ideological premises and our existing conditions that our vision is hampered. I know that mine is. But I feel confident in the superiority of the reordered values from which I am working, and I believe in our human capacity to cliange and imagime change.

Something is terribly wrong with our social-econormic-political system when we have repeated instances of mass harms and toxic poisonings caused by corporate activities or products. And the situation continues to worsen. When we try to solve the problem by relying on money, we dig ourselves deeper into the same pit. To alter our consciousness about solutions for personal injuries, we need to prioritize values other than dollars and economic growth, and we need to develop remedies other than money damages. We should look to values of human health, safety, and digmity, values of democratic participation, values of relationships and carmg. These values are already part of our vocabulary. We use them in legal opimions, in our conversations, in our reactions to harms, and in our social systems, but we end up giving them lip service instead of acting upon thein in tort law. This is a place for feminist (re)torts.

We cannot say that values of care and safety are antithetical to human nature because every day we find powerful examples of human sharing, support, and responsibility. We just have to figure out how to transfer that inethod of relating to others and that way of acting into a new legal paradigm. We have to jiggle those values loose from their hallowed pedestals where they shine brightly but have no effect.

Substantial changes like these-changes in the priorities of our values and in our underlying assumptions-cannot happen overniglit. But if we do not imagme change, work for it, and think through it, it will not occur at all. If we say these changes cannot occur because money is the only language understood by tort law and busmess, then we can never improve our situation, and we will always remain on the edge of a liability crisis. Half the battle is changing low we think about things. We must start somewhere.

\section{CONCLUSION}

I lave tried to sliare several thoughts in this Article. First, the tort system lias been wrongly blamed for a hability crisis that is the resnlt of corporate violence and the political-legal structure of our nation. Tort law does not create injuries. It neitlier defines the permissible structures for corporate organizations nor does it set the limits on corporate power. Tort law also does not create the social norms that value money and efficiency over health or safety. When our legal and political structures 
permit relatively unchecked accumulations of wealth and power in corporate for-profit enterprises and when criminal or civil sanctions are erratically imposed on corporations for their harm-causing or riskimposing behavior, the stage is set for the problems of mass tort law. Mass tort victims have been accused of greed and abuse of the system, but in fact it is the ijured parties who have been abused by corporations' greed and abuse. Corporations undemocratically impose health and safety risks on the public in their pursuit of private profit. When a rape victim testifies about the crimie perpetrated against her, our legal system questions whether sle is telling the trutl, whether slie invited or consented to the harm, and whetlier whit she endured is "real harm." When a mass tort victim testifies about the harm or risk imposed upon lier, our legal system questions whether she is telling the trutl, whether she invited the harm or consented to it, whether it is a real harm, and whether she is just after a quick buck. Rather than deal directly with male violence to eliminate rape, we turn our attention to the victim as the possible problem. Rather than deal with corporate violence and corporate organizational forms, misplaced priorities, and lack of interpersonal responsibility to end mass torts, we turn our attention to the victim and limiting access to the tort system. I ask us to examine this practice and refocus our attention on the real sources of harm.

Feminist theories and metloods offer new ways to think about mass torts cominitted by profit-seeking corporations. Feminism teaches us that systeins assumed to be neutral and necessary are in fact biased, and that systems like legal systems are based on implicit, unstated assumptions that favor tliose in power. ${ }^{175}$ It asks us to examine our social-political-legal structures for ways in which power is reinforced and groups or persons are subordinated or undervalued. Fennimism also suggests alternative perspectives on liuman interconnection and responsibility. Applying these insiglits, I looked at some aspects of the legal and social system that foster corporate liarm-causing and risk-imposition: the false dicliotoinies of public/private and imdividual/collective that fail to capture the nature of corporate actions, thereby creating a legal environment unable to impose appropriate responsibility on corporations and their decisionmakers for their liarms; a commodified system of remedies in which injury, justice, and responsibility are translated into dollar values; and the misallocation of the burden of proof and the presumption of liability on the less-empowered plaintiff in mass tort cases-a plienomenon that ignores the enormously greater power and resources available to corporate defendants. These aspects of our social and legal system which fos-

175. See Minow, supra note 105 , at $47-49$. 
ter risk miposition are ripe for feminist (re)torts. Based on a feminist conception of einpowerment, I have suggested shifting the burden of proof and persuasion in mass tort to the party empowered with knowledge, resources, access to information, and familiarity with the potentially harm-causing activity. I also suggested shifting the presumption of nonliability to the less empowered party, which means that a risk-creating defendant corporation initially would be presumed liable or responsible for victims' economic losses until the defendant corporation decides to hitigate the liability issue and wins.

Relying on feminist ethical insights about care and responsiveness to needs, I liave suggested that we need to reconsider our value priorities and assumptions. If healtll, safety, well-being, environmental clean-up, personal relationships, and care are truly our most iniportant values, then we cannot make them secondary to interests of efficiency or profit in tort law litigation. If healtli and well-being are what we would choose for ourselves in our daily lives, we also should choose them for society as a whole. We must learn that liealth and safety are not imcompatible with or in tension with efficiency or economic progress: One need not be exchanged for the other. Ironically, the values of health, safety, and personal/community well-being have been articulated for years. In this paradigm shift we do not need to change these values, but we will need to be sincere about them this time instead of permitting them to be overridden by private pursuits of profit. Paradigm shifts are difficult, but they clearly liave liappened in the past and can liappen now as well.

As part of this change, we must reconsider what it means to find a corporate defendant and its officers or decisionmakers responsible for harms and for their remedies. If responsibility can be expanded to mean responsiveness to the needs of others (from their perspective), then corporate and corporate officer responsibility would entail direct, interpersonal earegiving.

What kinds of remedies would respond better to injured persons' needs and the goals of making tortfeasors more socially and personally responsible? I do not know. This is something about which we all must brainstorm. There are lots of questions left unresolved. We will have to create rules that govern corporate organization in a way that requires each person in the organizational chain to take responsibility (in the power and choosing sense) for lier/his actions and the consequences. We can require corporate executives literally to sign every decision they make and let tliem know that they will be lield responsible. The tort system will have to make sure tliat plaintiffs always can identify the individuals who are responsible (those individuals who had the power to make decisions or affected those decisions) and impose on them both 
kinds of post-event responsibility-responsibility in the reparations sense and the needs-based responsive caregiving sense. Caregiving responsibility would be non-delegable, and it would attach to both specific individuals as well as any persons filling specified corporate roles. We also can create real incentives for corporate einployees to identify health and safety risks and prevent harms and mechanisms through which the pubhic can gain access to internal corporate information about the products and activities that create risks and harms. We can estabhish laws requiring all chief executive officers to live in the neighborhoods where their factories or plants are located so that their families would be subject to the healtli risks and toxins in the air, earth, and groundwater if the plant emits thein.

Our imagination is our only limit. In the criminal law systen, for exainple, we have developed community service obhigations as social "recompense" for crime. Initially, there were grave doubts about this prograin's possibilities for success, but it lias been impleinented successfully. We could develop interpersonal and community service obligations as legal "recounpense" for tort as well. For exainple, corporations that cause certain kinds of harms, such as injuries to women's reproductive systems, could be required to use their own laboratories, clinics, and einployees to researcli new reproductive technologies. Corporate officers could be required to use their skills to manage or direct tliese organizations for the benefit of the victims or to inanage and work in hospitals, nursing homes, educational facilities, and whatever else might be appropriate. Harm-causing scientists and researchers could be required to find answers and research new technologies to benefit their victims. Corporate officers can be mandated to personally do the pliysical clcan-up work at toxic dunıps or chemical/oil spills-froin cleaning off oil-soaked birds and shorehines to wearing insulated suits and scrubbing contaminated areas. These solutions are the easiest because they more closely replicate community service in criminal law and are variations on traditional monetary requireinents to fund projeets for the benefit of tort victims. In addition, those saine defendants could be required to respond directly to the needs of one or more of their victims. That response could start with personal apologies to each victim, ${ }^{176}$ followed by interpersonal, caregiv-

176. For example, the head of a Japanese airline personally visited the families of each of the victims of an airline crash to express his deep concern and to apologize. Hiroshi Wagatsuma \& Arthur Rosett, The Implications of Apology: Law and Culture in Japan and the United States, 20 LAW \& Soc'Y REV. 461, 488 (1986). That kind of action is a good start. There are stories galore about how victim's anger continues in the absence of sincere apology. For just one poignant example, see the article by Elaine Holstein, inother of one of the victims of the Kent State massacre, who discusses the absence of apology twenty years after the event. Elame Holstein, And Still No Honest Apology, N.Y. Times, Apr. 23, 1990, at A19, col. 2. 
ing work. It is hard to imagine how the tort system could make corporate defendants and corporate decisionmakers respond with direct interpersonal caregiving. But if that is our goal, and we work for it, then we can make it happen. It was probably hard to imagine strict products hability or medical inonitoring damages fifty years ago. ${ }^{177}$

There is nothing natural or necessary about legal responsibility meaning solely financial compensation, since we have other meanings of responsibility in our vocabulary of personal relations, and we have been able to integrate those ineanings in our social system without problem. We can figure out how to implement then in our legal system too. Once we have freed our thinking from the constramts of our prior economic, rights-based model, we can be creative and thoughtful about the possibilities of other-than-1nonetary tort remedies. This Article does not have "the answers," but $I$ hope it is a start of new questions about underlying assumptions of our social-political-legal organization. In the spirit of dialogue these feminist retorts can help us think about real, possible changes.

177. See Ayers v. Township of Jackson, 202 N.J. Super. 106, 493 A.2d 1314 (1985), aff'd in part, rev'd in part, 106 N.J. 557, 525 A.2d 287 (1987) (medical momitoring); RESTATEMENT (SECOND) OF TORTS § 402A (1965) (strict products liability). See also Allan Kanner, Medical Monitoring: State and Federal Perspectives, in Preparation and Trial of A Toxic TORT Case 549 (Practising $L$. Inst. 1988, Litigation Series No. 363) (examination of federal and state statutes governing medical surveillance claims). 